\title{
Intercomparison of satellite retrieved aerosol optical depth over ocean during the period September 1997 to December 2000
}

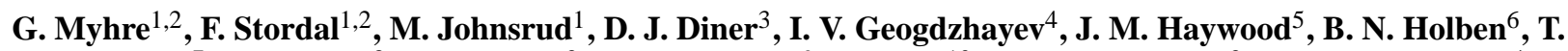 \\ Holzer-Popp $^{7}$, A. Ignatov ${ }^{8}$, R. A. Kahn ${ }^{3}$, Y. J. Kaufman ${ }^{9}$, N. Loeb ${ }^{10}$, J. V. Martonchik ${ }^{3}$, M. I. Mishchenko ${ }^{4}$, N. R. \\ Nalli $^{8}$, L. A. Remer ${ }^{9}$, M. Schroedter-Homscheidt ${ }^{7}$, D. Tanré ${ }^{11}$, O. Torres ${ }^{12}$, and M. Wang ${ }^{13}$ \\ ${ }^{1}$ Norwegian Institute for Air Research (NILU), Kjeller, Norway \\ ${ }^{2}$ Department of Geosciences, University of Oslo, Oslo, Norway \\ ${ }^{3}$ Jet Propulsion Laboratory, California Institute of Technology, Pasadena California, USA \\ ${ }^{4}$ NASA Goddard Institute for Space Studies, New York, New York, USA \\ ${ }^{5}$ Met Office, Exeter, UK \\ ${ }^{6}$ Biospheric Sciences Branch, NASA Goddard Space Flight Center, Greenbelt, Maryland, USA \\ ${ }^{7}$ Deutsches Zentrum für Luft- und Raumfahrt e.V. (DLR), Deutsches Fernerkundungsdatenzentrum (DFD), \\ Oberpfaffenhofen, Germany \\ ${ }^{8}$ NOAA/NESDIS/Office of Research and Applications/Climate Research and Applications Division, Washington, D.C., USA \\ ${ }^{9}$ Laboratory for Atmospheres, NASA/Goddard Space Flight Center, Greenbelt, Maryland, USA \\ ${ }^{10}$ Center for Atmospheric Sciences, Hampton University, Hampton, VA., USA \\ ${ }^{11}$ Laboratoire d'Optique Atmosphérique, Université de Lille/CNRS, Villeneuve d'Ascq, France \\ ${ }^{12}$ Joint Center for Earth Systems Technology, University of Maryland Baltimore County, Baltimore, Maryland, USA \\ ${ }^{13}$ University of Maryland-Baltimore County, NASA Goddard Space Flight Center, Greenbelt, Maryland, USA
}

Received: 4 October 2004 - Published in Atmos. Chem. Phys. Discuss.: 15 December 2004

Revised: 2 May 2005 - Accepted: 6 June 2005 - Published: 8 July 2005

\begin{abstract}
Monthly mean aerosol optical depth (AOD) over ocean is compared from a total of 9 aerosol retrievals during a 40 months period. Comparisons of AOD have been made both for the entire period and sub periods. We identify regions where there is large disagreement and good agreement between the aerosol satellite retrievals. Significant differences in AOD have been identified in most of the oceanic regions. Several analyses are performed including spatial correlation between the retrievals as well as comparison with AERONET data. During the 40 months period studied there have been several major aerosol field campaigns as well as events of high aerosol content. It is studied how the aerosol retrievals compare during such circumstances. The differences found in this study are larger than found in a previous study where 5 aerosol retrievals over an 8 months period were compared. Part of the differences can be explained by limitations and deficiencies in some of the aerosol retrievals. In particular, results in coastal regions are promising especially for aerosol retrievals from satellite instruments particularly suited for aerosol research. In depth analyses explain-
\end{abstract}

Correspondence to: G. Myhre

(gunnar.myhre@geo.uio.no) ing the differences between AOD obtained in different retrievals are clearly needed. We limit this study to identifying differences and similarities and indicating possible sources that affect the quality of the retrievals. This is a necessary first step towards understanding the differences and improving the retrievals.

\section{Introduction}

Satellite retrievals of aerosols and clouds have given much insight into the problem of quantification of the direct and indirect aerosol effects (e.g. Husar et al., 1997; Kaufman and Fraser, 1997; Nakajima and Higurashi, 1998; Boucher and Tanre 2000; Nakajima et al., 2001; Tanre et al. 2001; Rosenfeld, 2000; Rosenfeld et al., 2002; Koren et al., 2004). However, significant uncertainties remain regarding the radiative and climate effect of aerosols of anthropogenic origin (Haywood and Boucher, 2000; IPCC, 2001; Ramanathan et al., 2001; Kaufman et al., 2002a). For the direct aerosol effect uncertainties exist both due to limited information on spatial and temporal variation in the aerosol optical properties and

(C) 2005 Author(s). This work is licensed under a Creative Commons License. 
Table 1. Description of aerosol satellite retrievals.

\begin{tabular}{|c|c|c|c|c|}
\hline Satellite instrument & AVHRR-1* & AVHRR-2 & TOMS & SeaWiFS \\
\hline Responsible scientists & A. Ignatov & $\begin{array}{l}\text { M. Mishchenko and I. } \\
\text { Geogdzhayev }\end{array}$ & O. Torres & M. Wang \\
\hline References & Stowe et al., 1997, 2002 & $\begin{array}{l}\text { Mishchenko et al., 1999, } \\
\text { 2003; Geogdzhayev et } \\
\text { al., 2002, } 2004\end{array}$ & Torres et al., 1998, 2002 & Gordon and Wang, 1994 \\
\hline Aerosol microphysics & $\begin{array}{l}\text { Spherical particles, with } \\
\text { mono-modal log-normal } \\
\text { size distribution }(\mathrm{Rm}=0.1 \\
\mu \mathrm{m} \text { in } \mathrm{dN} / \mathrm{dR} \text { representa- } \\
\text { tion; } \Phi=2.03 ; \mathrm{n}=1.40-0 \mathrm{i})\end{array}$ & $\begin{array}{l}\text { Spherical aerosols with } \\
\text { a power-law size distri- } \\
\text { bution. The refractive } \\
\text { index is wavelength in- } \\
\text { dependent and includes } \\
\text { some aerosol absorption } \\
(\mathrm{n}=1.5-0.003 \mathrm{i})\end{array}$ & $\begin{array}{l}\text { Three aerosol types: sul- } \\
\text { fate, carbonaceous and } \\
\text { desert dust. Lognormal } \\
\text { size distributions. Pre- } \\
\text { scribed real ref. Index for } \\
\text { each aerosol type. Imag. } \\
\text { ref. index is retrieved. }\end{array}$ & $\begin{array}{l}\text { Shettle and Fenn (1979) } \\
\text { aerosol models. Bi- } \\
\text { modals log-normal size } \\
\text { distributions. Values of } \\
\text { single scattering albedo } \\
\text { from } 0.93-1.0 \text { at } 865 \mathrm{~nm}\end{array}$ \\
\hline $\begin{array}{l}\text { Channels used in the re- } \\
\text { trieval }\end{array}$ & $630 \mathrm{~nm}$ & 650 and $850 \mathrm{~nm}$ & $\begin{array}{l}331 \text { and } 360 \mathrm{~nm} . \\
\text { Reported at } 380 \mathrm{~nm} .\end{array}$ & 765 and $865 \mathrm{~nm}$ \\
\hline Spatial resolution & Equal-area $(110 \mathrm{~km})^{2}$ & $\begin{array}{l}\text { AVHRR } 4 \mathrm{~km} \text { GAC } \\
\text { (Global Area Coverage) } \\
\text { data subsampled at } 30 \mathrm{~km}\end{array}$ & $40 \times 40 \mathrm{~km}$ & $1 \mathrm{~km}$ \\
\hline Cloud mask & $\begin{array}{l}\text { Clouds from AVHRR } \\
\text { (CLAVR) (Stowe et al., } \\
\text { 1999) }\end{array}$ & $\begin{array}{l}\text { Modified ISCCP cloud } \\
\text { detection scheme as de- } \\
\text { scribed in Mishchenko et } \\
\text { al. (1999) }\end{array}$ & $\begin{array}{l}\text { Threshold of } 360 \mathrm{~nm} \\
\text { reflectance and TOMS } \\
\text { Aerosol Index informa- } \\
\text { tion. }\end{array}$ & $\begin{array}{l}\text { Uses threshold of the } \\
\text { TOA reflectance at } \\
865 \mathrm{~nm} \text { (Rayleigh contri- } \\
\text { bution corrected) }\end{array}$ \\
\hline $\begin{array}{l}\text { Special limitations for the } \\
\text { monthly mean products }\end{array}$ & $\begin{array}{l}\text { Fixed aerosol micro- } \\
\text { physics and lack of } \\
\text { on-board calibration in } \\
\text { AVHRR visible bands }\end{array}$ & $\begin{array}{l}\text { Cutoff threshold for AOD } \\
\text { of } 1.0 \text { at } 550 \mathrm{~nm}\end{array}$ & Large pixel size & $\begin{array}{l}\text { Cutoff threshold for AOD } \\
\text { of } 0.3 \text { at } 865 \mathrm{~nm}\end{array}$ \\
\hline
\end{tabular}

* The differences between AVHRR-1 (2g) and AVHRR-1 (3g/QC) are (i) that an additional quality control is performed for AVHRR-1 (3g/QC) (Ignatov and Stowe, 2002b), (ii) two channels are used in the retrieval (630 and $830 \mathrm{~nm}$ ), (iii) and another radiative transfer code is used to calculate the look-up-table (Vermote et al., 1997). The AVHRR-1 (3g/QC) is documented in Ignatov and Nalli (2002), Ignatov and Stowe (2002a), Ignatov et al. (2004).

the composition of the aerosols. Of particular importance is the fact that the crucial parameter single scattering albedo is poorly quantified. Satellite data have greatly improved the knowledge about the distribution of aerosols in the atmosphere. Given the complicated task of retrieving aerosol information from satellite instruments (King et al., 1999), it was perhaps not surprising that Myhre et al. (2004) showed, by comparing 5 satellite aerosol retrievals over ocean for an eight month period (November 1996 to June 1997), that substantial differences in aerosol optical depth (AOD) are present. In general, they found differences in AOD of a factor of two between the different datasets, but in some regions it was even higher. The best agreement in AOD was found in coastal regions with high AOD, whereas the largest discrepancies were found over large areas of remote oceanic regions in the southern hemisphere. Cloud screening was implicated as probably one of the main reasons for the large disagreement.
In this study we investigate AOD over ocean from several satellite aerosol retrievals over a 40 months period from September 1997 until December 2000. This is a much longer period than studied in Myhre et al. (2004) and allows investigation of inter-annual variability in AOD. For this period, 4 different aerosol satellite retrievals are investigated that were producing data for the entire period. Out of these 4 retrievals, 3 were also used in the intercomparison study in Myhre et al. (2004). In addition we focus on two shorter time periods; (i) an 8 months period with one additional satellite aerosol retrieval and two supplementary versions of one of the four main retrievals, (ii) a 10 months period with two additional retrievals for dedicated aerosol research. A particularly interesting issue is to see how the long term monitoring satellite retrievals compare to retrievals from satellite instruments especially suited for monitoring of aerosols (e.g. such as POLDER, MODIS, MISR). 
Table 1. Continued.

\begin{tabular}{|c|c|c|c|c|}
\hline Satellite instrument & VIRS & GOME/ATSR $2^{a}$ & $\operatorname{MODIS}^{a}$ & $\operatorname{MISR}^{a, b}$ \\
\hline Responsible scientists & A. Ignatov & $\begin{array}{l}\text { T. Holzer-Popp and M. } \\
\text { Schroedter }\end{array}$ & L. Remer & $\begin{array}{l}\text { D. Diner, R. Kahn, J. Mar- } \\
\text { tonchik }\end{array}$ \\
\hline References & $\begin{array}{l}\text { Ignatov (2003); Ignatov } \\
\text { and Stowe }(2000) \text {; Igna- } \\
\text { tov et al. }\left(2005^{1}\right)\end{array}$ & $\begin{array}{l}\text { Holzer-Popp et al., 2002a } \\
\text { and } 2002 \mathrm{~b}\end{array}$ & $\begin{array}{l}\text { Tanré et al., 1997; Remer } \\
\text { et al., } 2005\end{array}$ & $\begin{array}{l}\text { Martonchik et al., 1998, } \\
2002 \\
\text { Kahn et al., 1998, } 2001\end{array}$ \\
\hline Aerosol microphysics & Same as for AVHRR-1 & $\begin{array}{l}\text { External mixing of } 6 \\
\text { basic components from } \\
\text { OPAC (Hess et al., 1998) }\end{array}$ & $\begin{array}{l}\text { Bi-lognormal distribution } \\
\text { created from choice of } 4 \\
\text { fine and } 5 \text { coarse modes. } \\
\text { All spherical. Refrac- } \\
\text { tive indices vary with } \\
\text { mode and wavelength. } \\
\mathrm{n}_{r}=1.36-1.53 \text {. } \mathrm{n}_{i}=0- \\
0.005 \text {. }\end{array}$ & $\begin{array}{l}24 \text { mixtures of up to } \\
3 \text { components, covering } \\
\text { small, medium, and large, } \\
\text { non-absorbing and partly } \\
\text { absorbing particles, along } \\
\text { with medium and } \\
\text { large, non-spherical min- } \\
\text { eral dust analogs }\end{array}$ \\
\hline $\begin{array}{l}\text { Channels used in the re- } \\
\text { trieval }\end{array}$ & 630 and $1610 \mathrm{~nm}$ & $\begin{array}{l}415-675 \mathrm{~nm}(10 \mathrm{GOME} \\
\text { bands }) / 658,864 \mathrm{~nm}\end{array}$ & $\begin{array}{l}550,660,870, \quad 1240, \\
1630 \text {, and } 2130 \mathrm{~nm}\end{array}$ & $672,867 \mathrm{~nm}$ \\
\hline Spatial resolution & $\begin{array}{l}\text { Variable typically (10- } \\
20 \mathrm{~km})^{2}\end{array}$ & $80 \times 40 \mathrm{~km}^{2} / 1 \times 1 \mathrm{~km}^{2}$ & $\begin{array}{l}500 \mathrm{~m} \text { reflectances used } \\
\text { to create } 10 \mathrm{~km} \text { AOD } \\
\text { product }\end{array}$ & $\begin{array}{l}17.6 \mathrm{~km} \text { product, based on } \\
16 \times 16 \text { regions aggregated } \\
\text { from } 1.1 \mathrm{~km} \text { pixel data }\end{array}$ \\
\hline Cloud mask & $\begin{array}{l}\text { A CERES cloud iden- } \\
\text { tification developed by } \\
\text { NASA/LaRC (Trepte et } \\
\text { al., 1999) }\end{array}$ & $\begin{array}{l}1 \times 1 \mathrm{~km}^{2} \quad \text { combined } \\
\text { VIS/IR thresholds } \\
\text { APOLLO (Kriebel et al., } \\
1989 \text { and 2003) }\end{array}$ & $\begin{array}{l}\text { Spatial variability; IR } \\
\text { tests: } 1.38 \text { micron test for } \\
\text { cirrus. } \\
\text { (Martins et al., 2002) }\end{array}$ & $\begin{array}{l}\text { Multi-angle-based: Ra- } \\
\text { diative camera-to-camera } \\
(\mathrm{RCCM}) \text { and } \\
\text { Stereo-Derived cloud } \\
\text { masks (SDCM), plus } \\
\text { angular smoothness and } \\
\text { spatial correlation tests at } \\
\text { pixel resolution }\end{array}$ \\
\hline $\begin{array}{l}\text { Special limitations for the } \\
\text { monthly mean products }\end{array}$ & $\begin{array}{l}\text { Fixed aerosol micro- } \\
\text { physics }\end{array}$ & $\begin{array}{l}\text { Large pixel size } \\
\text { for GOME only } 3 \\
\text { days/month can be used } \\
\text { (acceptable pixel size) }\end{array}$ & & $\begin{array}{l}\text { Small swath width that re- } \\
\text { sults in few measurements } \\
\text { per month }\end{array}$ \\
\hline
\end{tabular}

${ }^{a}$ has also an aerosol retrieval over land

${ }^{b}$ MISR Aerosol Product Version 12 is used in this study. Upgrades to the aerosol climatology and low-light-level calibration, applied in Version 16 and higher, reduce MISR-derived AOD over dark water and under dusty conditions, improving the agreement with sun photometer observations, globally (Kahn et al., 2005). Refinements to the cloud-screening algorithm, currently under study, are expected to correct outliers that sometimes appear, especially at high latitudes, as illustrated in this study.

${ }^{1}$ Ignatov, A., Minnis, P., Loeb, N., Wielicki, B., Miller, W., Geier, E., Sun-Mack, S., Trepte, Q.: Aerosol retrievals from TRMM/VIRS over open ocean, J. Appl. Meteorol., in prep., 2005.

A significant advantage of our intercomparison of AOD in this 3 years period compared to the earlier intercomparison period is that much more ground based sunphotometer data from AERONET are available. This allows a broader comparison between the satellite aerosol retrievals and the AERONET measurements and furthermore an evaluation of under which conditions differences in the retrievals are largest. The aim of this study is to explore data for potential use by the global modelling community for comparing and improving global aerosol models. Hence validation of satellite data against AERONET in this study is done on spatial
(1 degree) and temporal (1 month) scales consistent with this task. Refinement of those scales is subject of future research. Finally, we also compare AOD from the various satellite retrievals in some selected regions and time periods with particular focus on e.g. episodes of large AODs or measurement campaigns. Also, we discuss whether differences in AOD are particularly large for e.g. certain satellite retrievals, oceanic regions, aerosol sizes, and ranges of AOD. 
Table 2. Location of AERONET stations used in the comparison.

\begin{tabular}{|c|c|c|c|c|}
\hline Name & Location & $\begin{array}{l}\text { Altitude } \\
\text { asl. (m) }\end{array}$ & \multicolumn{2}{|c|}{ Co-ordinates } \\
\hline Andros Island & Bahamas & 0 & 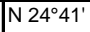 & W $77^{\circ} 47^{\prime}$ \\
\hline Anymon & Korea & 47 & N 36 $31^{\prime}$ & E $126^{\circ} 19^{\prime}$ \\
\hline Arica & Chile & 25 & S $18^{\circ} 28^{\prime}$ & W $70^{\circ} 18^{\prime}$ \\
\hline Ascension Island & South Atlantic & 30 & S $07^{\circ} 58^{\prime}$ & W $14^{\circ} 24^{\prime}$ \\
\hline Azores & North Atlantic & 50 & |N 38 $31^{\prime}$ & W $28^{\circ} 37^{\prime}$ \\
\hline Bahrain & Persian Gulf & 0 & N 26잉 & $\mathrm{E} 50^{\circ} 30^{\prime}$ \\
\hline Barbados & West Indies & 0 & N $13^{\circ} 09^{\prime}$ & W $59^{\circ} 30^{\prime}$ \\
\hline Bermuda & North Atlantic & 10 & N 322' & W $64^{\circ} 41^{\prime}$ \\
\hline Capo Verde & North Atlantic & 60 & N $16^{\circ} 43^{\prime}$ & W $22^{\circ} 56^{\prime}$ \\
\hline Coconut Island & Pacific Ocean & 0 & N $21^{\circ} 25^{\prime}$ & W $157^{\circ} 47^{\prime}$ \\
\hline Dakar & Senegal & 0 & N $14^{\circ} 23^{\prime}$ & W $16^{\circ} 57^{\prime}$ \\
\hline Dongsha Island & South China Sea & 5 & N $20^{\circ} 41^{\prime}$ & E $116^{\circ} 04^{\prime}$ \\
\hline Dry Tortugas & Florida & 0 & 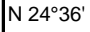 & W $82^{\circ} 47^{\prime}$ \\
\hline Goa & India & 20 & N $15^{\circ} 27^{\prime}$ & E $73^{\circ} 48^{\prime}$ \\
\hline Gotland & Sweden & 10 & N $57^{\circ} 55^{\prime}$ & E $18^{\circ} 56^{\prime}$ \\
\hline Helgoland & North Sea & 33 & N $54^{\circ} 10^{\prime}$ & $\mathrm{E} 07^{\circ} 53^{\prime}$ \\
\hline IMS METU ERDEMLI & Turkey & 0 & N 36³ & E $34^{\circ} 15^{\prime}$ \\
\hline Inhaca & Mozambique & 73 & $\mathrm{~S} 26^{\circ} 02^{\prime}$ & $E 32^{\circ} 54^{\prime}$ \\
\hline Kolimbari & Crete & 0 & |N 35⒊ & E $23^{\circ} 46^{\prime}$ \\
\hline Kaashidhoo & Maldives & 0 & N $04^{\circ} 57^{\prime}$ & $\mathrm{E} 73^{\circ} 27^{\prime}$ \\
\hline La Paguera & West Indies & 0 & N $17^{\circ} 58^{\prime}$ & W $67^{\circ} 02^{\prime}$ \\
\hline Lanai & Hawaii & 20 & N 204 $44^{\prime}$ & W $156^{\circ} 55^{\prime}$ \\
\hline Male & Maldives & 2 & $\mid N 04^{\circ} 11^{\prime}$ & E 733' \\
\hline Nauru & Pacific Ocean & 7 & S $00^{\circ} 31^{\prime}$ & E $166^{\circ} 54^{\prime}$ \\
\hline NCU Taiwan & South China Sea & 0 & N 24인 & E $121^{\circ} 05^{\prime}$ \\
\hline Rame Head & England & 0 & N $50^{\circ} 21^{\prime}$ & W $04^{\circ} 08^{\prime}$ \\
\hline Roosevelt Roads & West Indies & 10 & N $18^{\circ} 11^{\prime}$ & W $65^{\circ} 35^{\prime}$ \\
\hline San Nicolas & California & 133 & N $33^{\circ} 15^{\prime}$ & W $119^{\circ} 29^{\prime}$ \\
\hline Shirahama & Japan & 10 & N $33^{\circ} 41^{\prime}$ & E $135^{\circ} 21^{\prime}$ \\
\hline Swakopmund & Namibia & 250 & 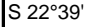 & E $14^{\circ} 33^{\prime}$ \\
\hline Tahiti & Pacific Ocean & 98 & S $17^{\circ} 34^{\prime}$ & W $149^{\circ} 36^{\prime}$ \\
\hline Venise & Italy & 10 & N 451' & $\mathrm{E} 12^{\circ} 30^{\prime}$ \\
\hline Wallops & Virginia & 10 & N $37^{\circ} 56^{\prime}$ & W $75^{\circ} 28^{\prime}$ \\
\hline
\end{tabular}

\section{Method}

For the comparison of satellite retrievals, data for the time period September 1997 to December 2000 have been collected. During this entire period, continuous AOD data from four satellite retrievals are available, namely AVHRR, (a one (AVHRR-1) and a two channel (AVHRR-2) retrieval), TOMS, and SeaWiFS. In addition AOD data from VIRS for an 8-month period (January to August 1998) are available. Further, two versions of the one channel AVHRR retrieval for the same time period are available. Since March 2000 data from the retrievals of the dedicated aerosol instruments MODIS and MISR (both onboard the Terra satellite) have become available, and thus we include 10 months of data for these retrievals. For MODIS version 4 data have been used. Due to the MISR capacity of multi angle viewing there is a rather small swath width for this instrument, requiring 9 days for full global coverage. Thus monthly mean datasets, which are used in much of this study, contain fewer data points in time for MISR than for the other retrievals. From September 1997 to August 1998 data for some limited regional areas covered by Meteosat- 8 domain are included for a retrieval based on a combination of GOME and ATSR2. The GOME/ATSR-2 retrieval yields only 3 days of measurements each month due to pixel size mode programming. Therefore monthly averages need to be compared with care.
It should be noted that this retrieval method was mainly developed for application over land and separation of the basic aerosol components. Due to the large GOME pixel size of $80 \times 40 \mathrm{~km}^{2}$ retrieval values at coastal sites may be dominated by AOD values derived from dark surface reflectances over land. AVHRR has been producing data since 1981 and TOMS, except for a break from 1992 to 1996, since 1979. September 1997 was chosen as the first month of the comparison because this was the first month with AOD data from SeaWiFS. Currently, the SeaWiFS data processing is optimized for the ocean color measurements. As a result, very thick aerosol AOD cases such as the dust and smoke plumes are usually masked out due to large uncertainties in the ocean color products in these cases. Recall also that SeaWiFS is lacking thermal infrared band, thus significantly complicating separating of aerosol from cloud. SeaWiFS has a reflectance threshold at $865 \mathrm{~nm}$ corresponding to AOD of $\sim 0.3$ above which aerosol retrievals are discarded. Thus, the SeaWiFS AOD is mostly applicable and valid in the open ocean regions (Wang et al., 2000a; Wang et al., 2000b). It should be noted that AVHRR-2 has a similar AOD threshold of 1.0 at $550 \mathrm{~nm}$. Table 1 gives a short description of the 8 retrievals.

The AOD data are reported for different wavelengths; AVHRR-1 at $630 \mathrm{~nm}$, AVHRR-2 at $550 \mathrm{~nm}$, SeaWiFS at $865 \mathrm{~nm}$, TOMS at $380 \mathrm{~nm}$, VIRS at $630 \mathrm{~nm}$, GOME/ATSR2 at $550 \mathrm{~nm}$, MODIS at $550 \mathrm{~nm}$, and MISR at $558 \mathrm{~nm}$. For comparison in this study, we convert the AOD data for the different wavelengths to the AOD at $550 \mathrm{~nm}$. For SeaWiFS the Angström coefficient reported as part of the SeaWiFS data product is used for conversion. The AVHRR-1 data and the VIRS data have been converted using the Ångström coefficient from AVHRR-2. For TOMS a provisional estimate of AOD at $550 \mathrm{~nm}$ is made by scaling the $380 \mathrm{~nm}$ values with the monthly mean ratio between $550 \mathrm{~nm}$ and $380 \mathrm{~nm}$ AOD values from TOMS from the period 1979 to 1992 for each grid point. For AVHRR-2, MODIS, GOME/ATSR-2 and MISR the reported wavelength are used. All the satellite data are compared for a $1 \times 1$ degree grid on a monthly mean basis.

The satellite retrievals are compared with ground based AOD measurements from AERONET (Holben et al., 1998). Because the satellite retrievals in this comparison mostly include data over ocean only, measurements from AERONET stations located on islands and near coastlines are used. Even so, the grid square where the station is located will in many cases be predominantly over land and therefore have no AOD value from the satellite retrievals. The AERONET data are therefore compared to an average of 9 (3 in latitudinal and 3 in longitudinal direction) $1 \times 1$ degrees grid squares of satellite data, where the ground station is located in the centre grid square. Note that the comparison of satellite data to the AERONET data is similar to a model to AERONET comparison, since currently horizontal resolution is around 3 degrees in many global models. Based on the MODIS data, which are also retrieved over land, the assumption of using 9 

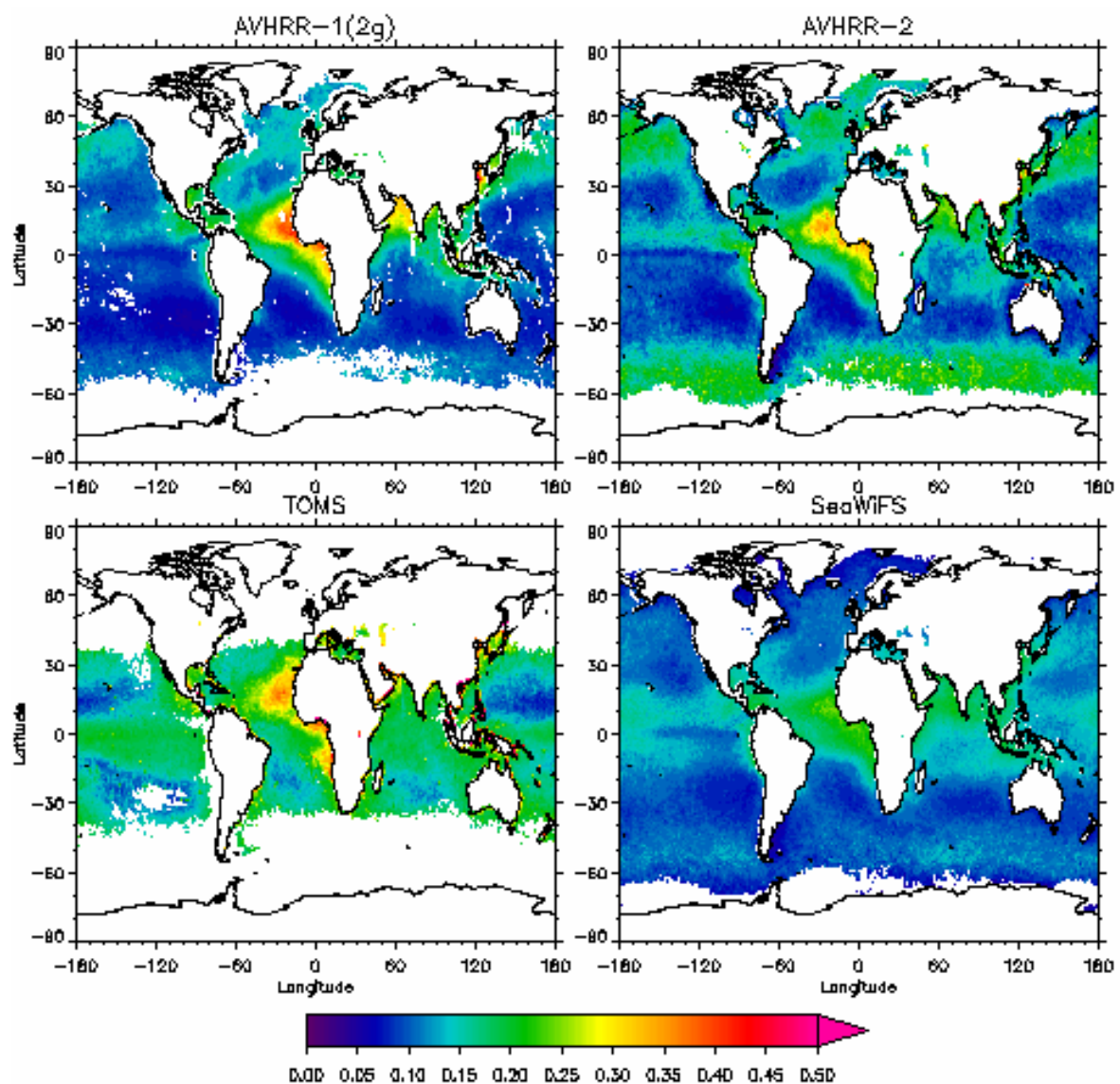

Fig. 1a. Averaged AOD $(550 \mathrm{~nm})$ over ocean for the period Sep 97-Dec 00. Values are given with minimum of data for ten months. Maximum 1-degree monthly average AOD is 0.72, 1.00, 1.57, and 0.28, respectively for AVHRR-1(2g), AVHRR-2, TOMS, and SeaWiFS.

grid points instead of 1 in the comparison with AERONET is investigated. The results of this investigation is presented in Appendix 1, showing generally very similar results for 9 grid points compared to the closest grid point to an AERONET station. Out of 33 AERONET stations used in this study and listed in Table 2, this assumption seems unsatisfactory for only 3 stations.

\section{Intercomparison of satellite AOD}

Figure 1a shows the geographical distribution of AOD for a mean of 40 months for 4 satellite retrievals. The figure confirms results of many previous satellite studies that AOD is generally highest near continental regions. This is evident in all four data sets. The aerosol plume over the Atlantic west of Africa is clearly evident, with mineral dust dominating in the northern region and biomass burning dominating in the south and a mixture of these aerosols around Equator. As in Myhre et al. (2004) significant differences can be seen in the southern hemisphere at high latitudes. SeaWiFS has generally lower AOD than the three other retrievals. Figure $1 b$ and $c$ show the geographical distribution of AOD for the 2 sub periods. The VIRS data show a similar pattern in AOD as the 4 retrievals which are available for the whole period in this study. Note that VIRS coverage is limited from $\sim 38$ S-38 N, due to the orbital specifics of the Tropical Rainfall Measuring Mission (TRMM) platform. The magnitude in AOD for VIRS is most similar to AVHRR-1 and TOMS. GOME/ATSR-2 has a sparse geographical coverage of AOD but indicates gradients and AOD values west of Africa that are similar to the other aerosol retrievals. The improved quality control in AOD for AVHRR-1 reduces the coverage of AOD, but influences the magnitude of AOD only weakly where data are available.

MODIS and MISR have higher AOD values in many regions compared to the 4 other retrievals shown in Fig. 1c, with MISR AOD usually somewhat higher than MODIS values. The highest AOD values are off the coast of northwest Africa and at high latitudes. The magnitude in AOD varies somewhat between the various retrievals but the pattern in AOD in the tropical Atlantic Ocean is rather robust. The spatial coverage in different AOD in products is limited to those areas which get enough solar illumination to generate sufficient reflected energy to be detected from a satellite 

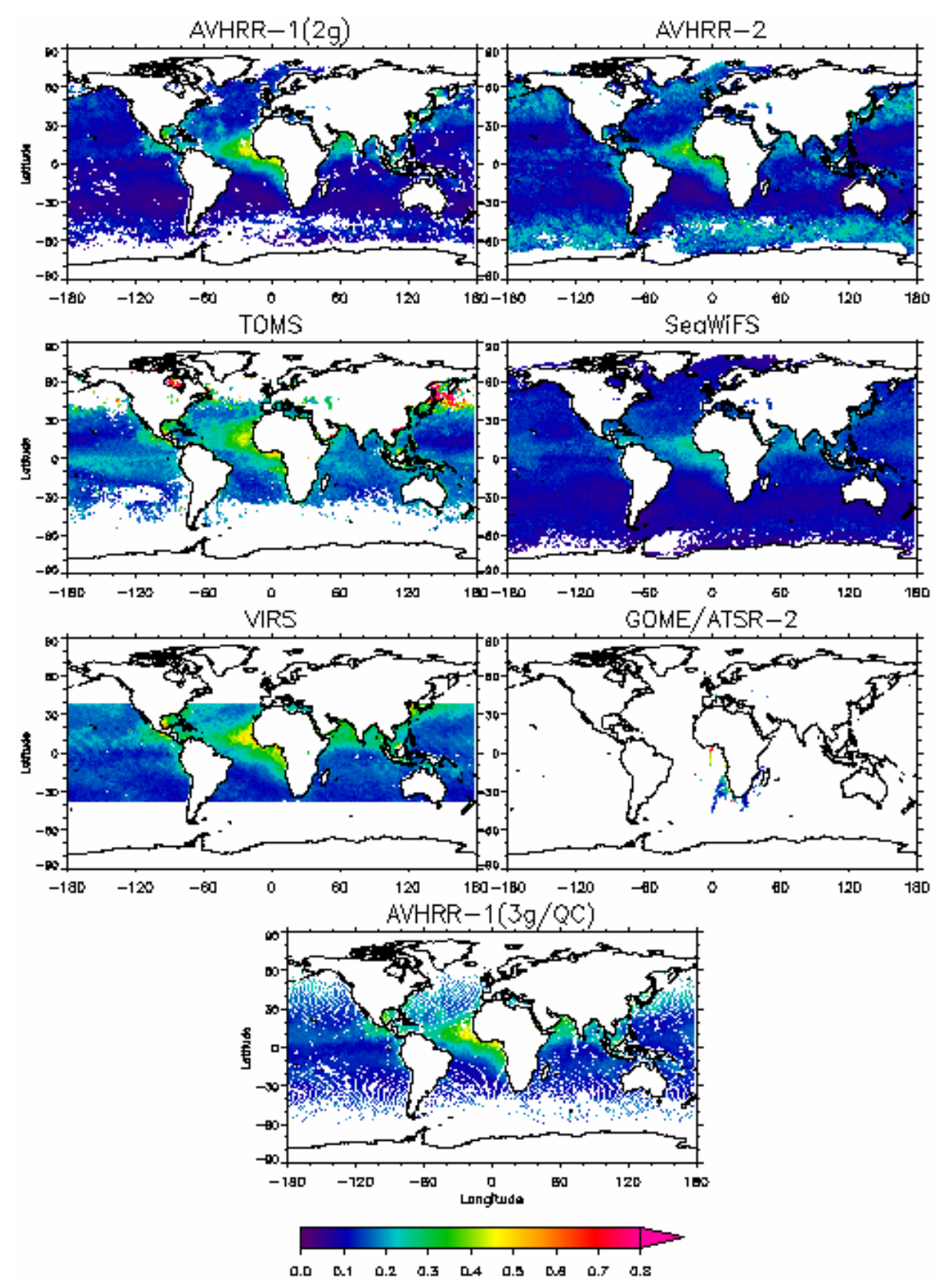

Fig. 1b. Averaged AOD $(550 \mathrm{~nm})$ over ocean for the period Jan to Aug 1998. Values are given with minimum of data for two months. Maximum 1-degree monthly average AOD is 0.95 for AVHRR-1(2g), 1.00 for AVHRR-2, 2.53 for TOMS, 0.35 for SeaWiFS, 1.31 for VIRS, 2.73 for GOME/ATSR-2, and 0.64 for AVHRR-1 (3g/QC).

in a specific orbit. It is interesting to see the values up to around 0.3 in the southern hemisphere and up to 0.6 in the northern hemisphere at high latitudes for MODIS and MISR. In the region in the southern hemisphere the aerosols are mainly sea salt and to some extent natural sulfate aerosols and episodic anthropogenic aerosols. This is a region with few AERONET measurements and has been identified in Myhre et al. (2004) as the region with largest difference between the various satellite retrievals. The high AOD in the northern Pacific is interesting and is a likely a combination of outflow of aerosols from the Asian continent and sea salt aerosols generated by the relatively high windspeeds in these regions. The Ångström Exponent is higher than in most of the other oceanic regions. The gradual decrease from the Asian Continent in this parameter indicates a combination of industrial pollution and sea salt aerosols. Note also the elevated AOD around $10-20^{\circ} \mathrm{N}$ in the eastern part of the Pacific Ocean which is seen to various extent in all the datasets. Two areas with particular differences are near the coast of China and the North Sea. In the former region the AOD varies 

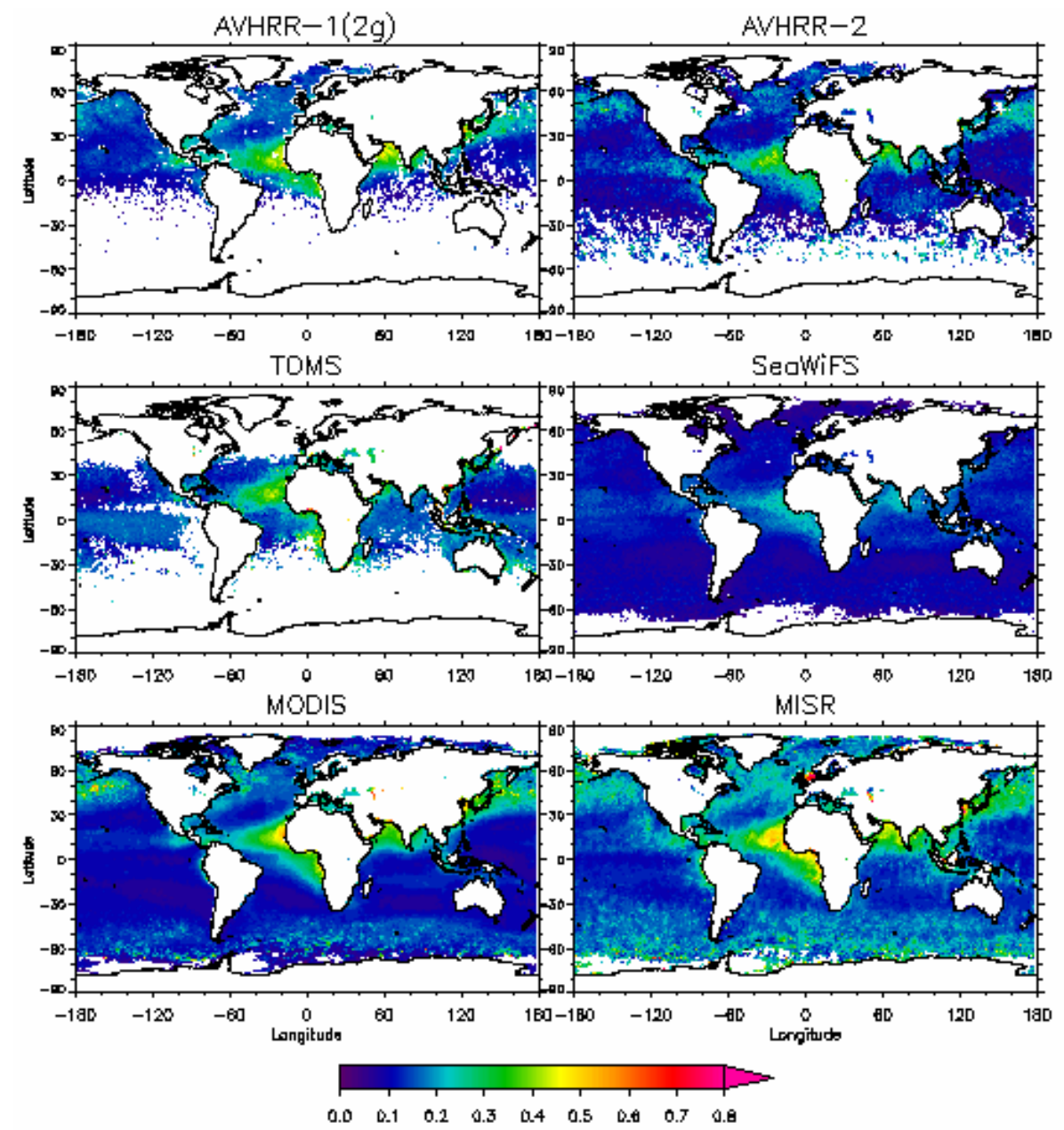

Fig. 1c. Averaged AOD $(550 \mathrm{~nm})$ over ocean for the period Mar to Dec 2000. Values are given with minimum of data for two months. Maximum 1-degree monthly average AOD is 0.81 for AVHRR-1, 1.00 for AVHRR-2, 2.53 for TOMS, 0.31 for SeaWiFS, 2.27 for MODIS, and, 1.62 for MISR. [Note that orbit of NOAA-14 satellite (launched late 1994) whose AVHRR data are used in this study significantly drifted towards later afternoon by year 2000, causing loss of AVHRR-1 retrievals at low sun in the upper left panel.]

gradually from about 0.2 to 1.0 . In the North Sea MISR shows a particularly high AOD.

In Fig. 2 the global mean of all the 8 data sets with global coverage are shown for the whole period. The global mean AOD differs by at least a factor of 2. AVHRR-2 and SeaWiFS have considerably weaker annual variability than the other data sets. The inter-annual variability differs somewhat between the AVHRR-1 and TOMS. The AOD from the VIRS retrieval is in the upper range of the AODs represented in the study. A variation over the 8 months can be seen in the VIRS data. Interestingly, a comparison between the 2 nd generation and 3rd generation AVHRR-1 product yields differences that are almost as large as differences between various aerosol retrievals on different satellite platforms. The two AVHRR products have similar temporal variation in AOD over the 8 months period. The yearly variation in global AOD is very similar for MODIS and MISR despite differences in their magnitude.

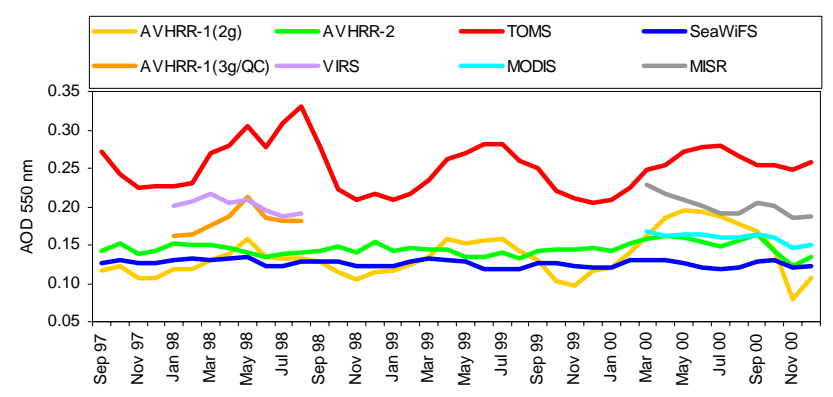

Fig. 2. Global and monthly mean AOD $(550 \mathrm{~nm})$ over ocean from September 1997 to December 2000.

Figure 3 shows the zonal mean AOD for the entire 40 month period (a), the 8 months period from January to August 1998 (b), and the 10 months period from March to December 2000. Similar to what was found in Myhre et 

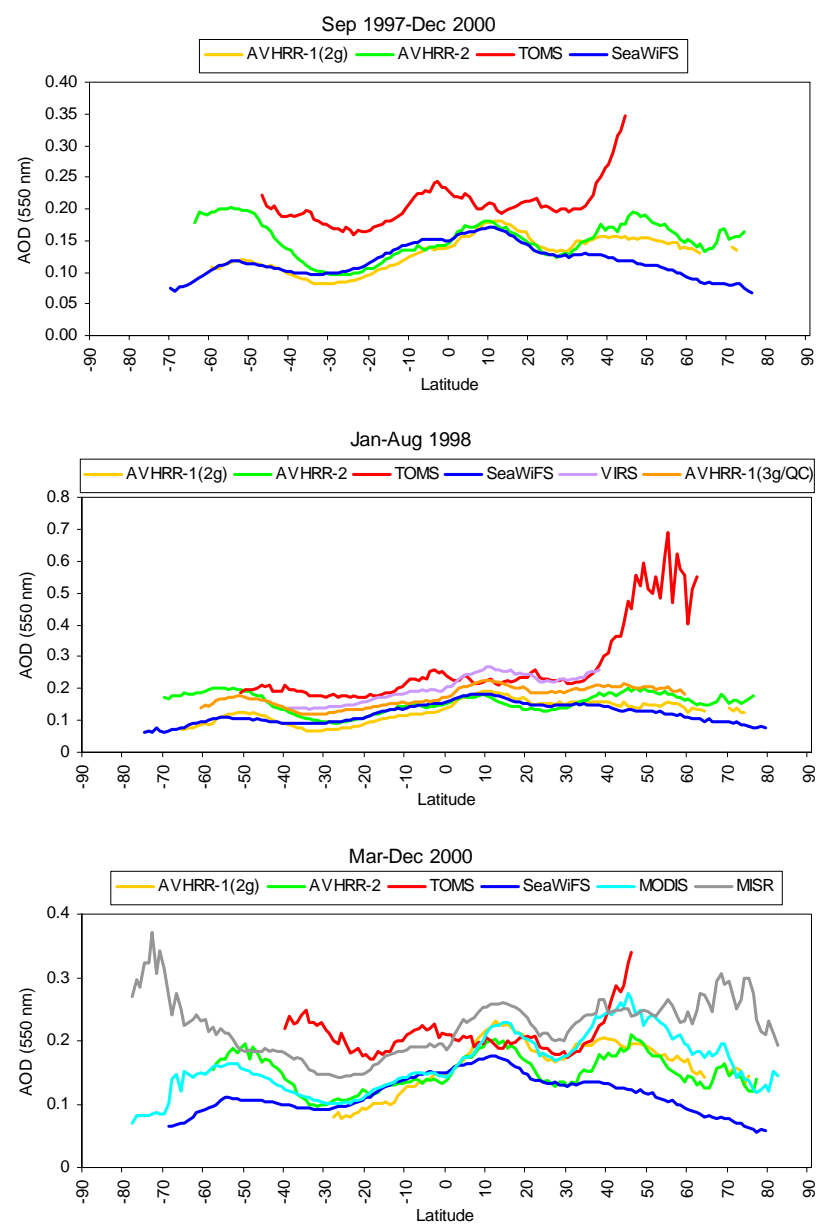

Fig. 3. Zonal mean AOD as a function of latitude, for the entire period of investigation, as well as for the two selected periods used in Figs. $1 \mathrm{~b}$ and $\mathrm{c}$.

al. (2004) the largest differences are found at high latitudes, whereas the results in tropical regions are generally more comparable. The largest differences between MODIS and MISR in the monthly mean are found at high latitudes, in particular in the southern hemisphere. For the entire period the differences are largest in the southern hemisphere, whereas in the latest sub period large differences are also found in the northern hemisphere. A common feature with local maxima near equator and at higher latitudes and local minima at 2030 degrees in both hemispheres can be seen to various extent in all the retrievals. Aerosol outflow from Africa, relatively high AOD in the Indian Ocean, and high AOD at higher latitudes fit into this picture

Figure 4 illustrates the annual cycle of AOD, and its interannual variability, over 4 large oceanic regions defined in Appendix $B$. The thick lines show the 40 months period mean AOD and the dotted lines show minimum and maximum AOD values during the same period. AVHRR-1 and TOMS have much larger inter-annual variability than AVHRR-2 and
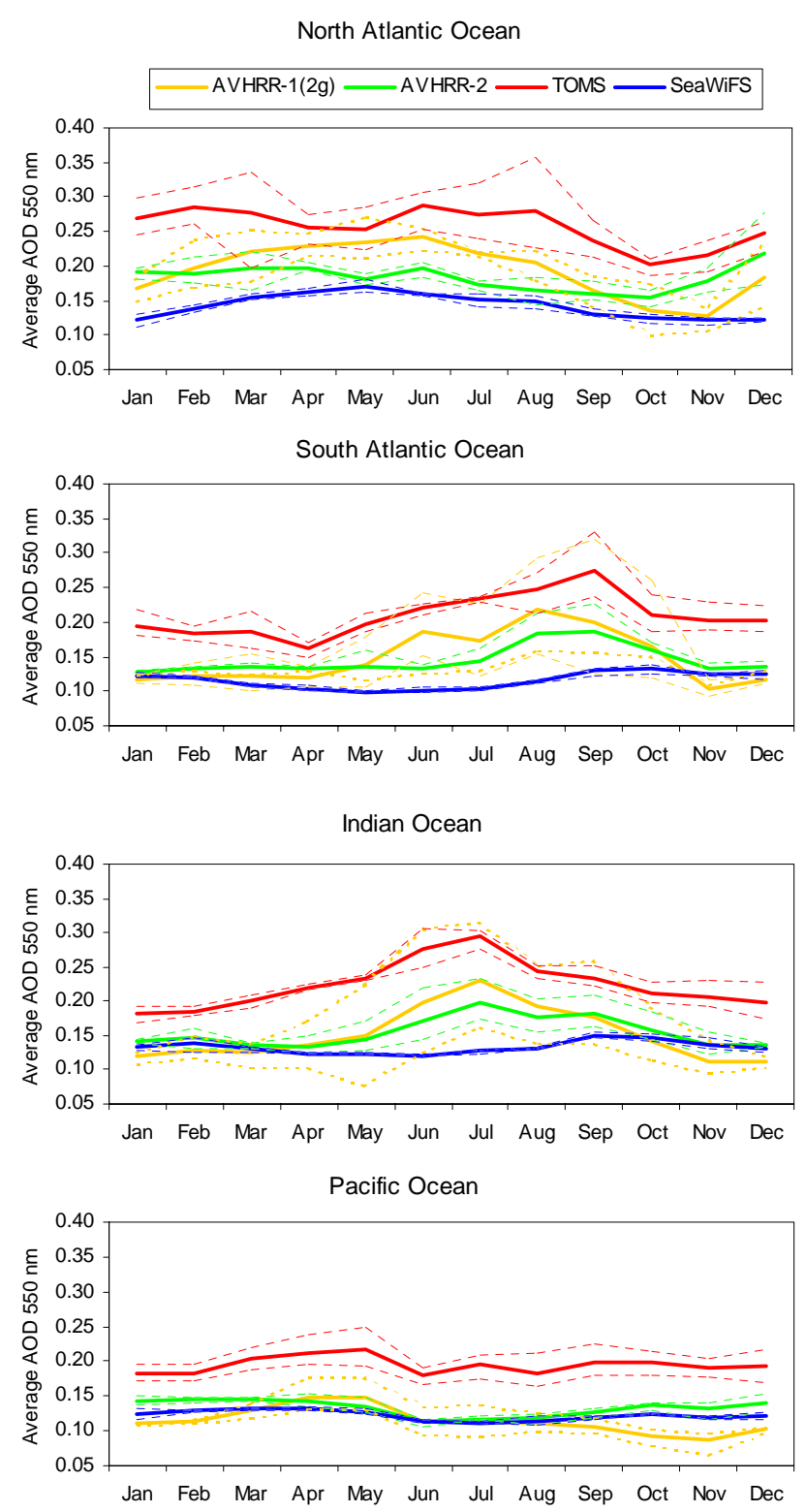

Fig. 4. Monthly mean AOD $(550 \mathrm{~nm})$ for four ocean regions (see definition in Fig. A2). The solid curves are averages for the entire period selected in this study. The dashed lines represents highest and lowest values among the years.

SeaWiFS. This is also indicated in Fig. 2a, but Fig. 4 shows that this is the case over all the 4 oceanic regions. Generally, AVHRR-1 and TOMS have a larger inter-annual variability from April to November than during the rest of the year.

Figure 5 shows AOD from the nine data sets for 11 smaller coastal regions, in an attempt to cover the oceanic regions with highest AOD. AOD is thus usually higher in these regions than the global mean. Further, in general the difference between the AOD from the various retrievals is smaller than for global averages and for larger oceanic regions, as 


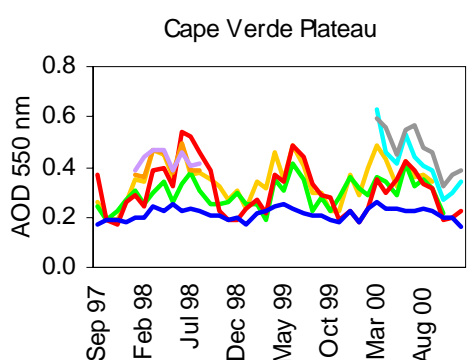

Arabian Sea

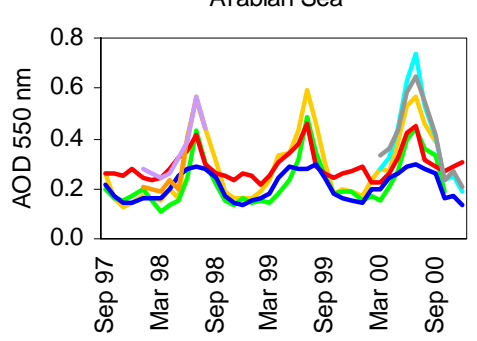

Black Sea

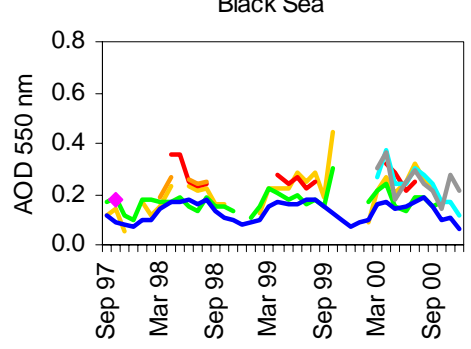

South China Sea

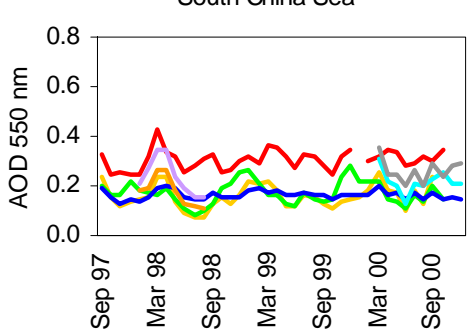

Angola Basin

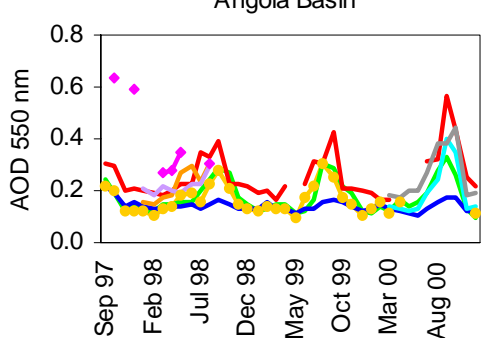

Bay of Bengal

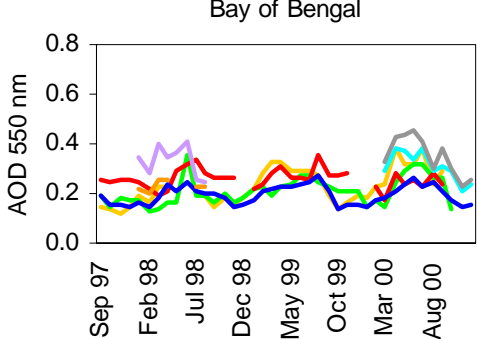

Caspian Sea

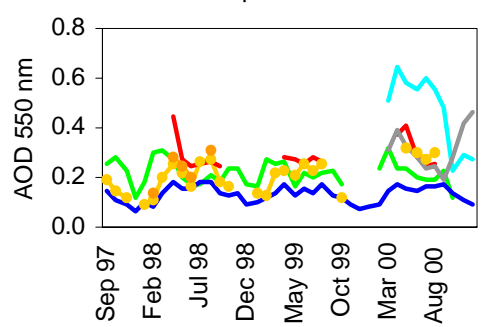

East China Sea and Sea of Japan

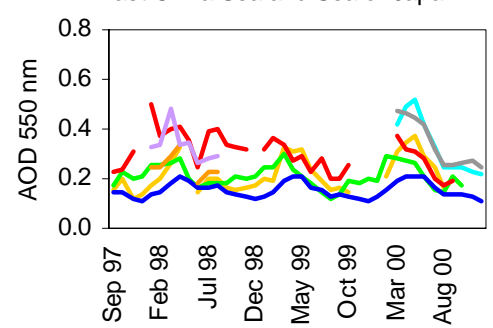

East Coast of USA

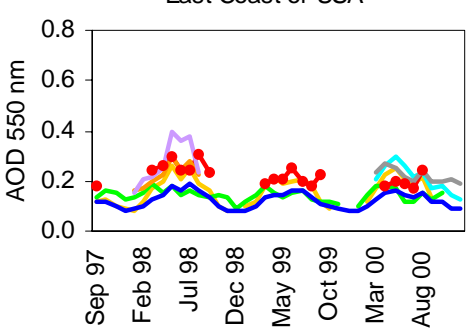

Red Sea

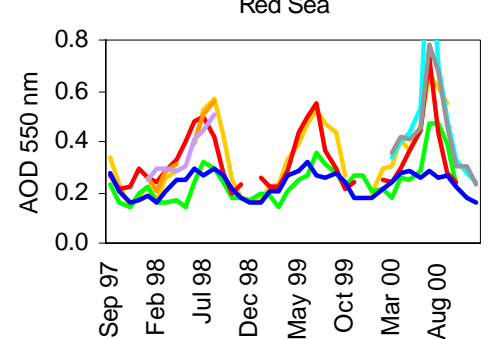

Mediterranean Sea
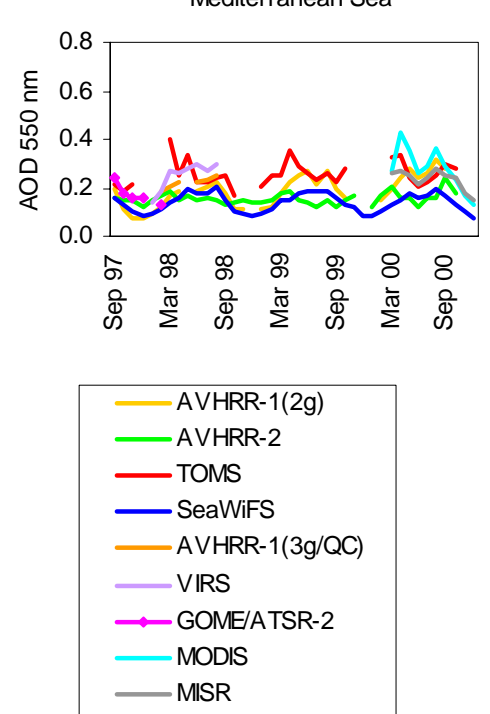

Fig. 5. Monthly mean AOD $(550 \mathrm{~nm})$ over ocean for 11 near coastal regions (see definition in Fig. A2).

found also in Myhre et al. (2004). In about half of the 11 regions a distinct seasonal variation in AOD can be seen. However, the seasonal amplitude varies between the satellite retrievals. For many of the retrievals the agreement is best at the East coast of USA, and over the Arabian Sea and the Red Sea. The differences between the two AVHRR-1 data sets are smaller than shown in Fig. 2 for global conditions. The VIRS data have many similarities with the AVHRR-1 data sets, although often with somewhat higher values. The agreement in AOD between MODIS and MISR is very good, except for the Caspian Sea where the difference between the retrievals is usually large. Further, there is a tendency that MODIS and MISR as well as GOME/ATSR-2 have higher AOD than the other retrievals.
In Fig. 5 an average value for each region was shown. However, despite two datasets having a similar average value, they may have a different spatial distribution. Figure 6 shows the spatial correlation coefficient between various retrievals for the months with common availability of data. The correlation coefficient between the 1-degree monthly average satellite retrievals is shown for the oceanic regions illustrated in Fig. 5 for six of the retrievals. The highest correlation coefficient is found for the Angola basin, the Red Sea, and the Arabian Sea, whereas the weakest correlation coefficient is identified in the Caspian Sea. Also in the Mediterranean Sea and the Black Sea the correlation coefficients are low. Two apparent explanations of the variations in the correlation coefficient for the regions are differences 

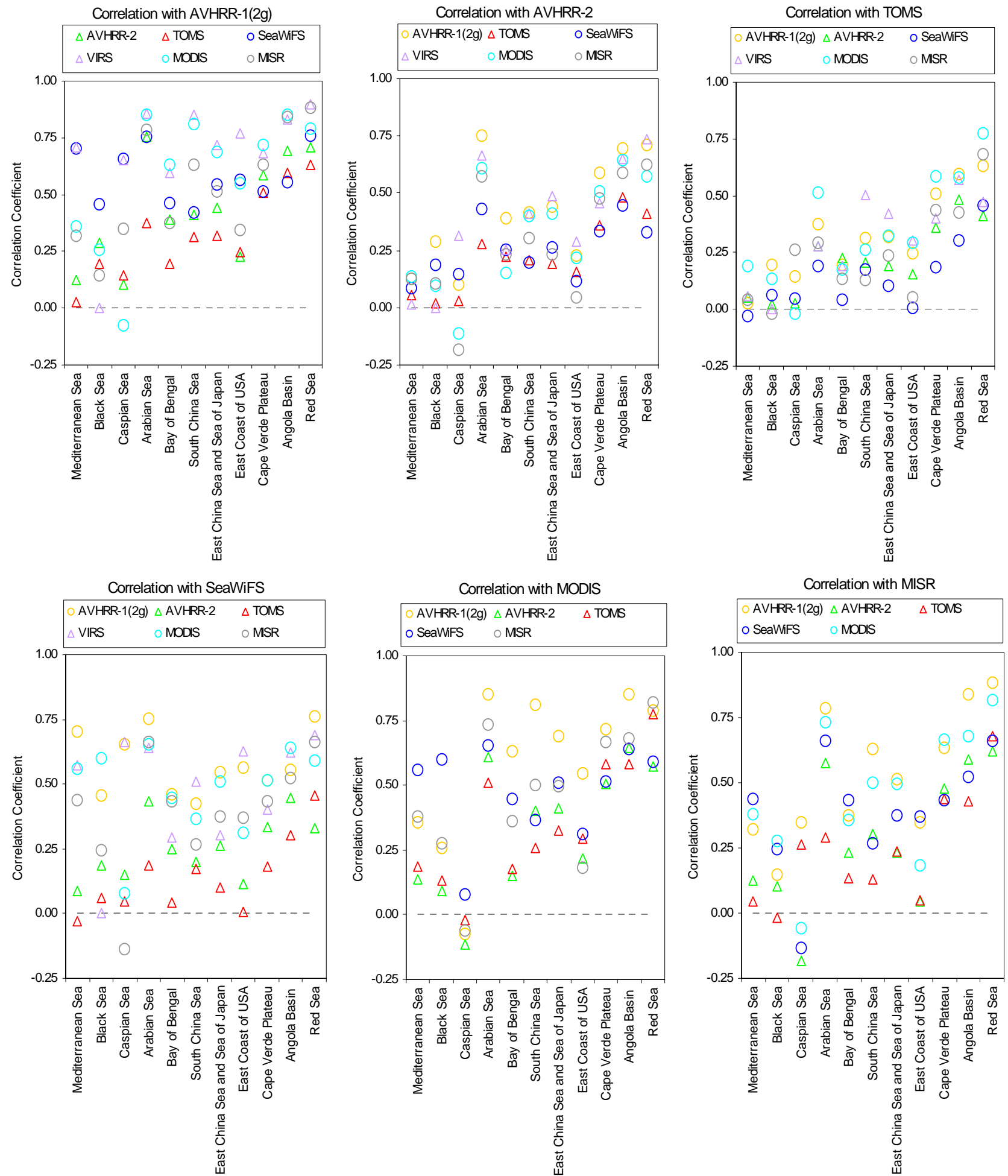

Fig. 6. Temporal average of spatial correlations on grid square level between AVHRR-1(2g), AVHRR-2, VIRS, TOMS, SeaWiFS, MODIS and MISR for the 11 regions (see definition in Fig. A2). 
in the temporal variation in AOD and variation in aerosol type and mixture. For a high temporal variation in AOD sampling issues are especially important. Further, variation in aerosol type and mixture may be problematic since most of the retrievals have pre-defined assumptions on absorption, and in many cases also on size. The Mediterranean Sea and Caspian Sea is likely to be dominated by aerosols from industrial pollution with episodic influence by mineral dust plumes. This yields significant temporal variation in AOD. Furthermore, and probably more important is the fact that many aerosol types and sizes are likely present, sometimes even in complicated internal mixtures. On the other hand the Angola basin and the Red Sea are mainly dominated by one aerosol type (besides some sea salt aerosols); namely biomass burning aerosols and mineral dust, respectively. For AVHRR-1 the correlation with other aerosol retrievals is usually high, not surprisingly it is generally best with VIRS but also highly correlated with MODIS and MISR. For AVHRR2, TOMS, and SeaWiFS the correlation with other retrievals is usually slightly lower than for AVHRR-1. The correlation between these three retrievals is low, and each of them are normally more strongly correlated to the four other retrievals. The spatial correlation between MODIS and MISR is high, with exceptions for the East coast of USA, the Black Sea, and especially for the Caspian Sea. However, it is interesting that AVHRR-1 often has even higher correlation with both MODIS and MISR than the internal correlation between MODIS and MISR. The internal correlation between MODIS and MISR is certainly influenced by the low temporal sampling of MISR as discussed above. Note here that in some regions the analysis with AVHRR-1 against MODIS and MISR is based on relatively few months due to data availability. Note also that retrievals in the coastal areas may be possibly affected by the surface reflectance, which may be elevated here over the background oceanic conditions.

The spatial and temporal variation in the aerosol distribution is large, and in some periods episodes of large aerosol amount can occur. This can either be due to large fires (of natural or anthropogenic origin), occurrences of large mineral dust outbreaks or when meteorological conditions favor high concentration of aerosols resulting from industrial activity. The aim of Fig. 7 is to illustrate how the various satellite retrievals compare under such circumstances. We have selected some episodes during the period of this study with high amounts of aerosols. Aerosol campaigns have taken place in many regions around the world, often focusing on areas with large AOD. In Fig. 7 we have included data from regions close to three aerosol campaigns (INDOEX, SAFARI 2000, and SHADE). The agreement between the satellite retrievals is best when AOD is generally low, and largest differences are found when AOD is high. In particular, the large biomass burning events in Indonesia in October 97 and Mexico in May 98 reveal the largest differences between the satellite retrievals. Actually, the differences can be as large as a factor 3-4. In regions dominated by industrial pollution

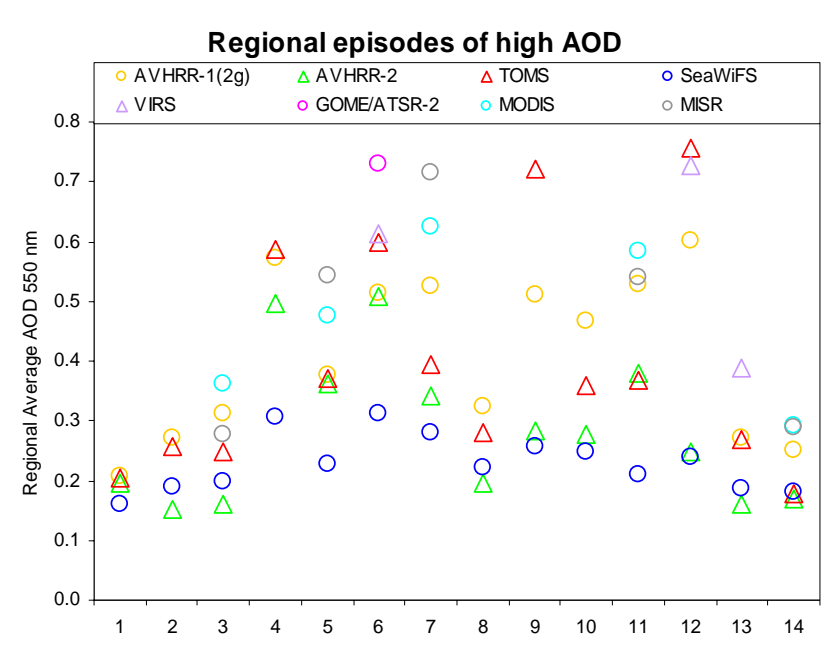

Fig. 7. Comparison of AOD from satellite retrievals for episodes with high AOD and for periods of aerosol campaigns, 1) Europe Atlantic Coast, Apr 99, 2) Mediterranean Sea, Aug 99, 3) Mediterranean Sea, Aug 00, 4) Cape Verde Plateau, Jun 99, 5) Cape Verde Plateau, Sep 00 (period of SHADE), 6) Angola Coast, Aug 98, 7) Angola Coast, Aug 00 (period of SAFARI2000), 8) Indian Coast, Mar 99 (period of INDOEX), 9) Indonesia, Oct 97, 10) China Sea, May 99, 11) China Sea Mar 00, 12) Mexico, May 98, 13) East Coast USA, May 98, 14) East Coast USA, May 00.

the results are generally similar or in better agreement than for global mean conditions. One explanation for the difference in the monthly mean AOD during events of high AOD is different sampling. This is related to different swath width and time of overpass that influence the cloud screening and glint mask. Therefore, we can expect that sampling issues are more evident in a small region with high variability than in the large temporal or spatial averages. The relative differences in AOD for the retrievals were greater for SAFARI 2000 than for INDOEX and SHADE, even when considering only the four retrievals with observations in all campaigns. The AOD was also larger for the region close to SAFARI 2000 than for the INDOEX and SHADE regions. AVHRR2 and SeaWiFS have usually the lowest values, most likely linked to the upper threshold values for AOD. For the cases including MODIS and MISR data these two retrievals have high AOD, and the agreement between them is good and generally better than the agreement between any other two retrievals.

\section{Comparison of AOD between aerosol satellite re- trievals and AERONET}

A large advantage compared to Myhre et al. (2004) is that in this study a much larger set of AERONET observations are available for comparison with the satellite retrievals. This is both due to a longer time period of investigation and to the fact that more AERONET stations were in operation. 

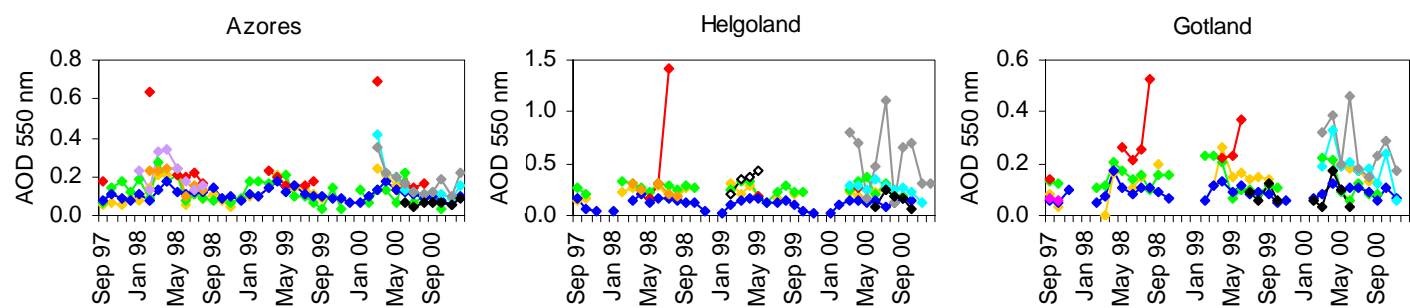

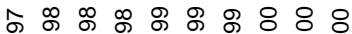

ஸे

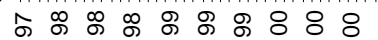

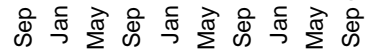
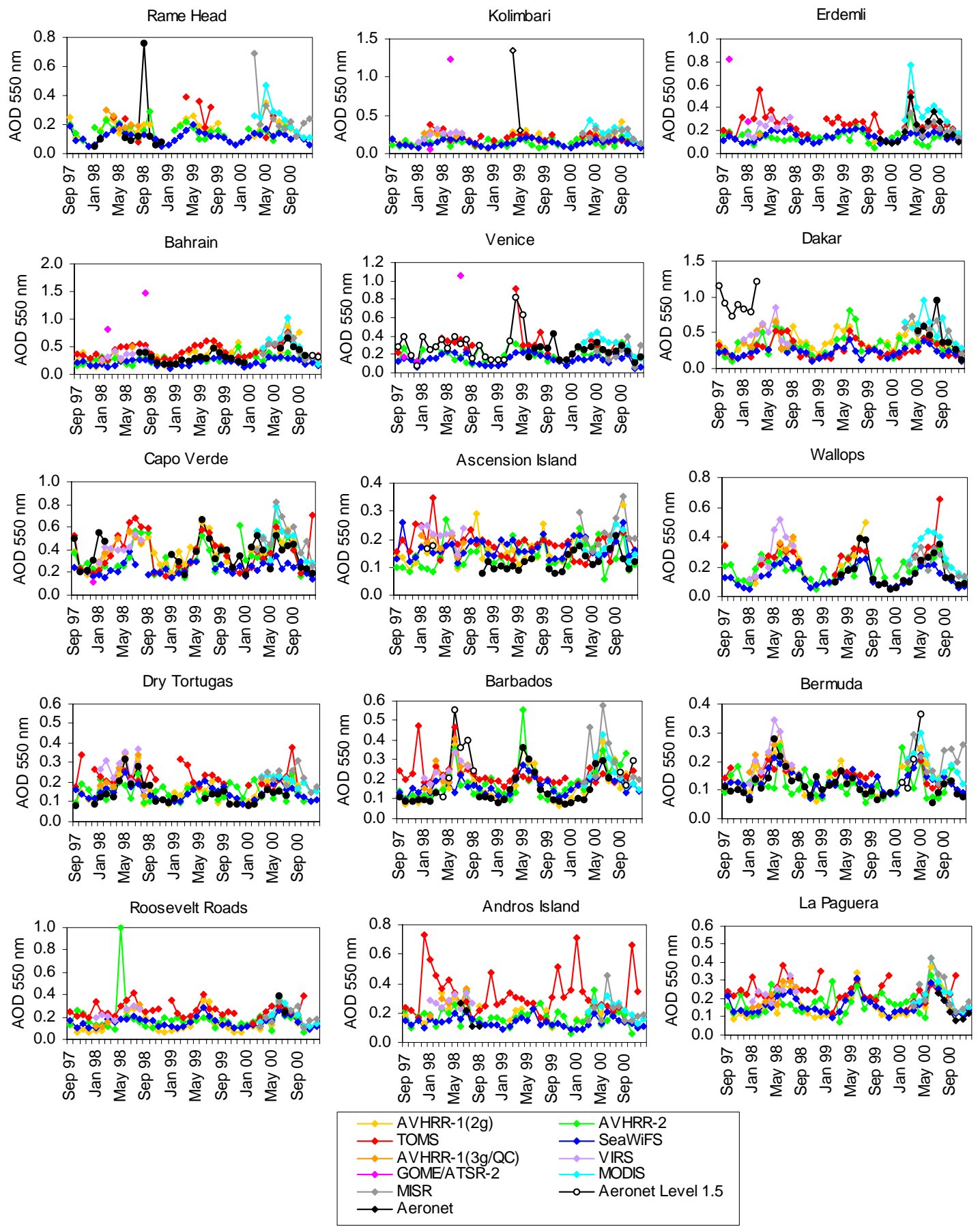

Fig. 8. Monthly mean AOD from AERONET and nine satellite retrievals. The satellite data are for 550 nm, while the AERONET data are mean values of $\mathrm{AOD}$ at 440 and $670 \mathrm{~nm}$ (500 and 670 at some stations). Note the different scales for AOD at different stations. 

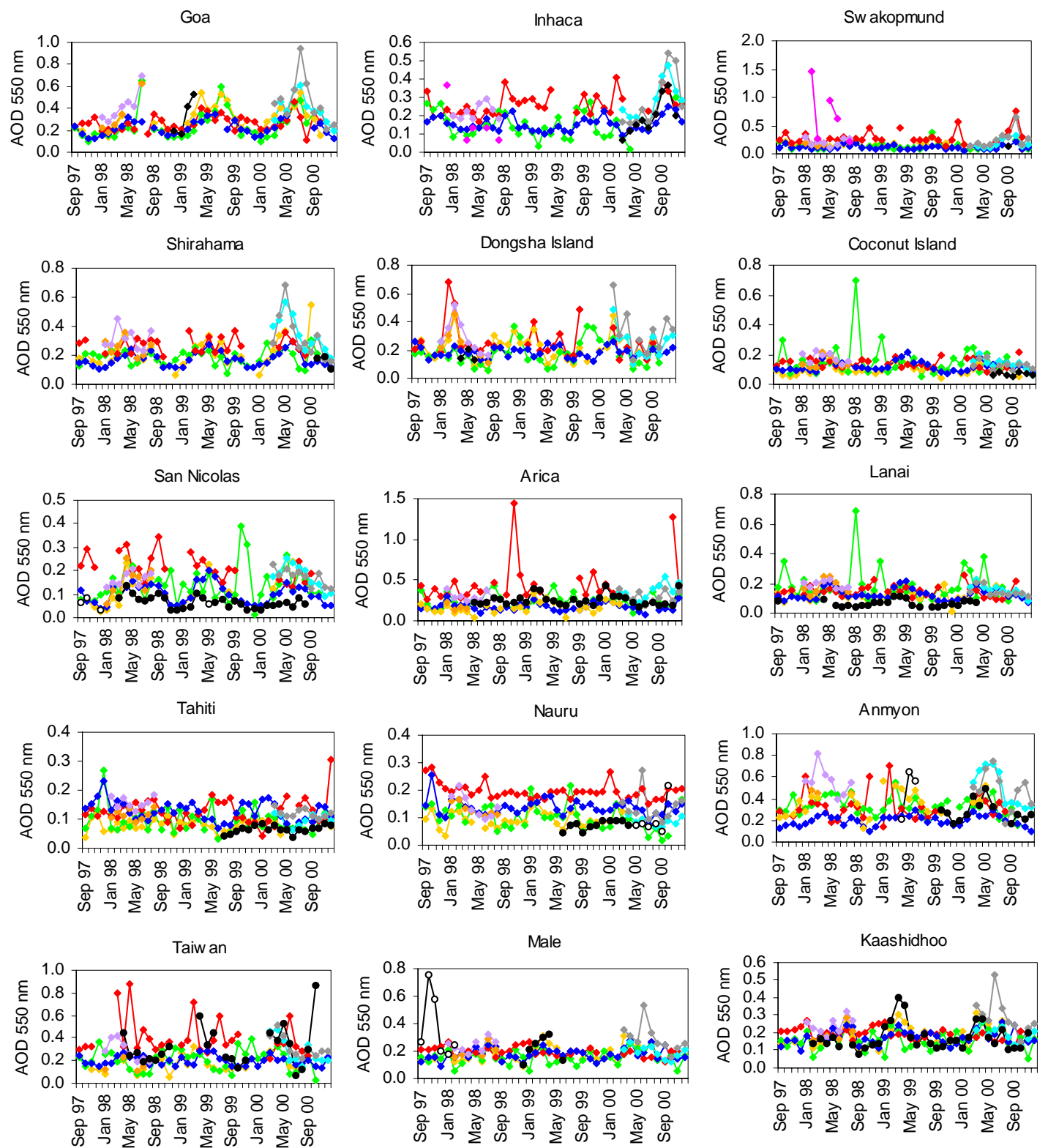

\begin{tabular}{|c|c|}
\hline $\begin{array}{l}\because \text { AVHRR-1 }(2 \mathrm{~g}) \\
\multimap \text { TOMS } \\
\multimap \text { AVHRR-1(3g/QC) } \\
\because \text { GOME/ATSR-2 } \\
\because \text { MISR } \\
\longrightarrow \text { Aeronet }\end{array}$ & $\begin{array}{l}\because \text { AVHRR-2 } \\
\because \text { SeaWiFS } \\
\multimap \text { VIRS } \\
\multimap \text { MODIS } \\
\multimap \text { Aeronet Level } 1.5\end{array}$ \\
\hline
\end{tabular}

Fig. 8. Continued.

Validations of the individual aerosol satellite retrievals have been performed for several of the satellite products (e.g. Stowe et al., 2002; Torres et al., 2002; Remer et al., 2002; Holzer-Popp et al., 2002b; Kahn et al., 2005; Liu et al. 2004). Comparison between the satellite retrievals and the AERONET as a function of time is shown in Fig. 8 for the 33 stations listed in Table 2. In general a good agreement is found between the AERONET and satellite retrievals, and seasonal and inter-annual variations seen in the AERONET data are mainly captured also in the satellite data. The best agreement between the AERONET data and the satellite retrievals are probably found at Wallops, Barbados, and Bermuda, whereas at Dakar significant differences are found in the first part of the period where we use the less validated AERONET level 1.5 data. 

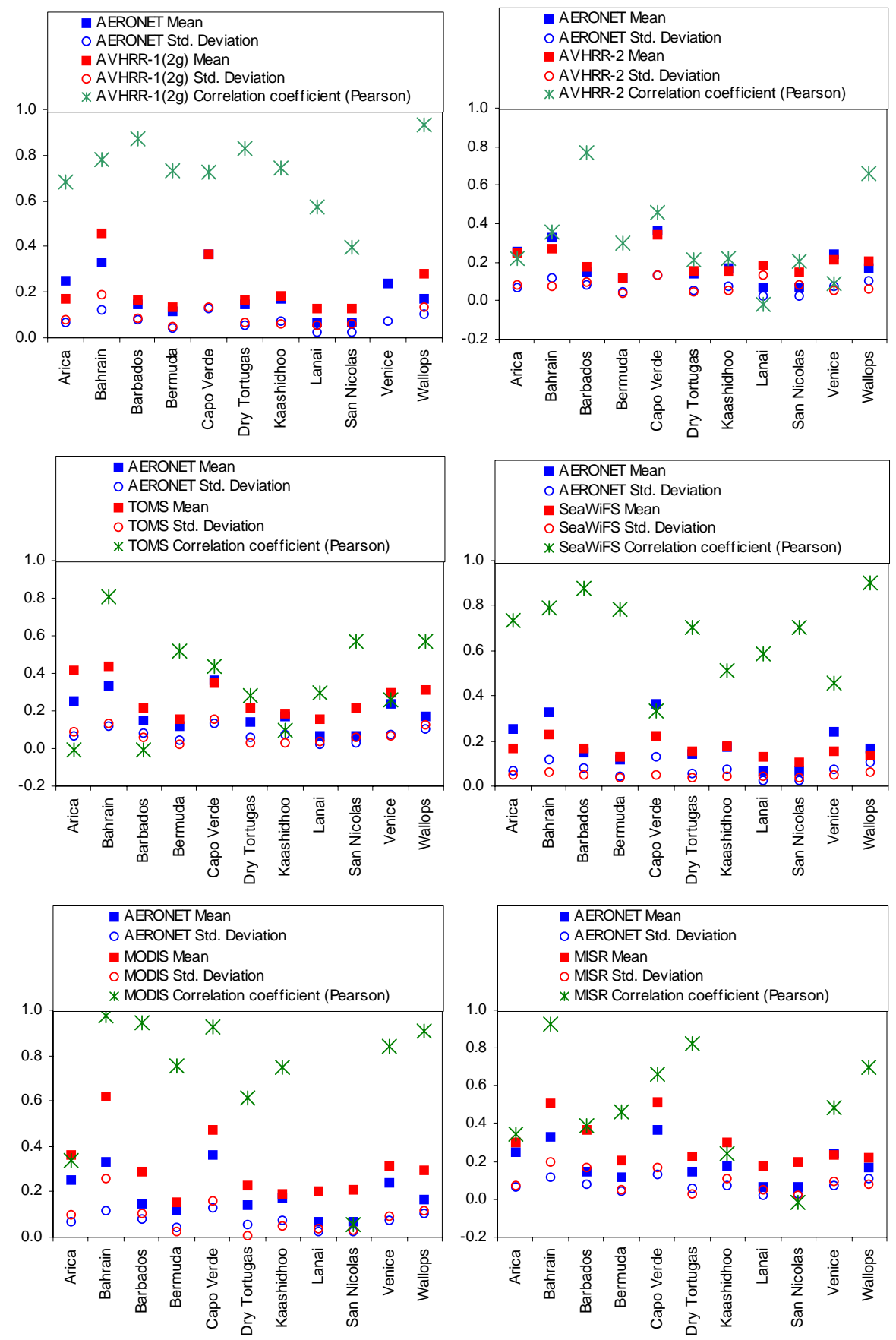

Fig. 9. AERONET and satellite mean AOD and standard deviation and the correlation coefficient between the satellite retrieval and AERONET data. 11 stations and six satellite retrievals (one in each panel) are included.

In Fig. 9 a subset of the AERONET stations with longest time series of observations are further studied. Mean and standard deviation for the AERONET data and satellite retrievals are given in the figure, as well as the corresponding correlation coefficient for each station. No obvious systematic differences in the satellite retrievals in their comparison with the AERONET averages are apparent. At Lanai and San
Nicolas the mean AOD is higher in all the satellite retrievals compared to the AERONET data. Otherwise no systematic differences can be found for the mean AOD. The standard deviation is smaller or equal in the AERONET data than in the satellite retrievals at Lanai and San Nicolas. SeaWiFS has in often the lowest standard deviations of the seven data sets. The correlation coefficient is usually high and there are no 
specific AERONET stations with a consistently low correlation coefficient. Bermuda, Bahrain, and Wallops are stations with the generally highest correlation coefficient, whereas for many of the satellite retrievals it is low at San Nicolas.

Note here that we use a rather large spatial resolution as described in Appendix 1 and the sub-scale spatial variation in AOD can be significant. In particular variation in relative humidity can influence the spatial variation (Haywood et al., 1997; Myhre et al., 2002; Anderson et al., 2003) as water uptake increases the AOD for hygroscopic aerosols considerably. Relative humidity is frequently higher close to clouds than in clear sky, and thus AOD may be higher closer to clouds. This is in fact what is found based on AERONET and cloud observations in Kaufman et al. (2002b) and also pointed out by Ignatov and Nalli (2002) and Ignatov et al. (2004) to be a possible explanation. On the other hand, clouds also wash out aerosols, reducing the AOD close to clouds. Koch et al. (2003) found that over land in Europe and North America that clouds and sulfate aerosols are anticorrelated, indicating that clouds are more efficient in washing out sulfate aerosols than in contributing to aqueous-phase production of sulfate aerosols. However, in which way AOD varies close to clouds should be investigated further, since there could be large regional variations and differences between cloud types and aerosol types. AERONET measurements are taken regularly when clouds are not present. In contrast, satellite retrievals occur in clear and cloudy sky conditions and cloud-screening procedure is the applied. This leads to analyze more instances over regions in the vicinity of clouds than in AERONET measurements.

Figure 10 shows scatter plots of the satellite retrievals against AERONET data for all the 33 stations included in this study. Note that for the eight retrievals shown in this figure the time period varies for which analysis are performed, and that we have removed level 1.5 data in the scatter plot analysis. There is a tendency that the satellite retrievals have a weak overestimation compared to AERONET for low AOD, but often underestimate high AOD from AERONET. This pattern varies significantly between the various retrievals. SeaWiFS has a good agreement with the AERONET data for low AOD, but the largest underestimation among the satellite data sets for high AERONET AOD values. This is what can be expected since this retrieval has a threshold value for AOD. TOMS has a very few high AOD values that are clear overestimates compared to the AERONET data. AVHRR-1, AVHRR-2, and VIRS differ also most compared to AERONET for high AOD values. MODIS and MISR have relatively more high AOD values than AERONET values compared to the other retrievals. However, these scatter plots reveal that particularly MODIS and partly MISR generally compare better to AERONET than the rest of the retrievals. Also AVHRR-1 has a slope indicating a good agreement with AERONET given all the uncertainties in this comparison which is based on monthly mean data. The two versions of AVHRR-1 differ significantly, due to different sampling and retrieval procedures used. Two issues regarding this analysis need to be emphasized. The AERONET data used in Fig. 10 are not the same for all retrievals due to differences in time periods. Considering only data in the 10 months period in 2000 impacts the results for AVHRR-1, AVHRR-2, TOMS, and SeaWifs compared to AERONET data to a limited extent. On the other hand including level 1.5 in this scatter analysis would reduce the agreement for these four retrievals with the AERONET data, in particular the underestimation of high AOD values.

When considering monthly means in the comparison of satellite retrievals with AERONET, data sampling issues are important. For the AERONET measurements high frequency data are averaged to daily means. However, the number of days that are included in the AERONET monthly mean of AOD is highly variable. Especially three AERONET monthly data points differ from the satellite retrievals, and they are all based on less than three days of measurements during the whole month. These are Dakar (1 day in August 2000), Taiwan (2 days in October 2000), and Rame Head (3 days in September 1998). Removing these data points from the analysis increased the slope of the regressionline for all satellite retrievals, except for VIRS and AVHRR$1(3 \mathrm{~g} / \mathrm{QC})$. For the other retrievals the slope of the regressionline changed from 0.04 to 0.26 , with the largest change for MODIS and thereafter MISR. Further, removing all AERONET data with less than three days of measurements during the whole month ( 30 out of a total of 488 data points) had a relatively small impact, less than 0.05 change in the slope of the regression-line compared to the case when only the three data points discussed above were removed. In most the cases the monthly mean data are based on more than 10 days of measurements. This is the case in 375 of the 488 AERONET monthly mean data used in this study.

For AVHRR-1(2g) a large difference from AERONET occurs mainly at Bahrain, in addition to the cases discussed above. However, removing the data points from Bahrain in the analysis influences the slope of the regression-line only to a small extent. For AVHRR-2, TOMS, and SeaWiFS there are no stations with particularly large differences compared to AERONET. For MISR a few AERONET stations reduce the slope of the regression-line significantly. These are in particular Helgoland and Gotland, and to some extent Taiwan (October 2000 as mentioned above). Removing these data from the analysis for MISR resulted in a regressionline slope of around 0.85 (also shown in Fig. 10), which is a typical value found in the global MISR validation paper by Kahn et al. (2005). The high MISR values at Helgoland and Gotland for MISR can be seen in Figs. 8 and 1c. The high values found in the North Sea for MISR are probably related to cloud screening and to the use of a climatology of the near-surface wind speed for the ocean white cap model. This may yield too high AOD under high wind events under cloud-free conditions (Kahn et al., 2005). Removing the same values in the analysis for MODIS as for 

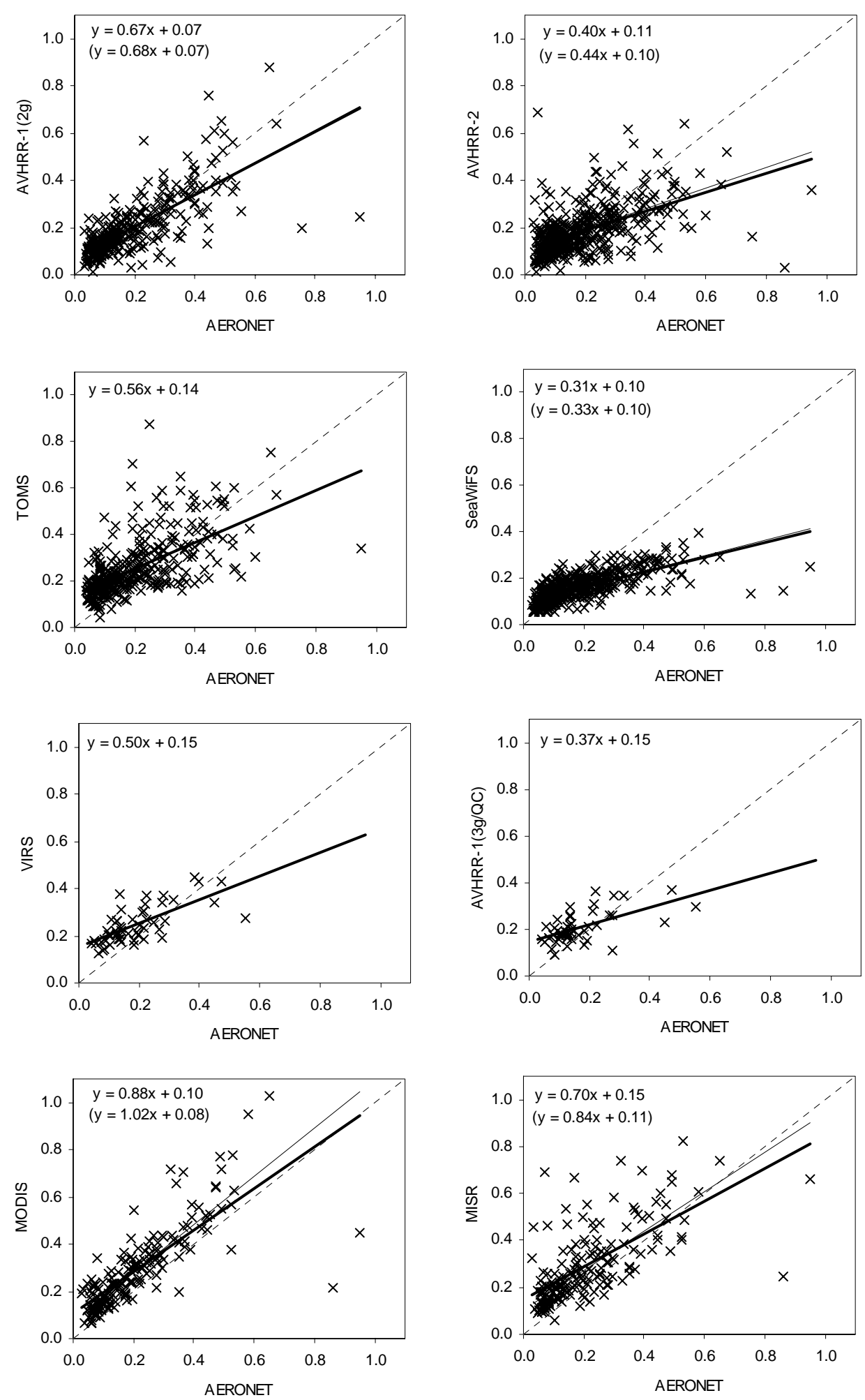

Fig. 10. Scatter plot of monthly mean AOD for AERONET data vs. eight satellite retrievals. Satellite data are given for $550 \mathrm{~nm}$, AERONET data are mean of 440 (500 for some stations) and $670 \mathrm{~nm}$. Results are also shown when values from Helgoland, Gotland (all data), and Taiwan October 2000 are removed from the analysis (thin lines, and equations in parenthesis). 
MISR increased the slope of the regression-line for MODIS similar to MISR. Whereas, our comparison with AERONET is based on monthly mean data, the study of Abdou et al. (2005) compare coincident MISR and MODIS AOD with AERONET data during 3 month in 2002 with MISR showing an agreement with AERONET which is at least as good as for MODIS.

In Fig. 11 the scatter plots of AERONET data and the satellite retrievals are divided into three groups according to the AERONET Ångström exponent to identify whether differences are related to the size of the aerosols, which is indicative of aerosol type. For AVHRR-1 and TOMS the results seem rather independent of the Ångström exponent. For AVHRR-2 the results indicate reduced agreement with the AERONET data for the smallest aerosols (high Ångström exponent). In the case of the SeaWiFS data, Fig. 10 indicates an underestimation of large AOD from AERONET. Fig. 11 indicates that this is least pronounced for the smaller particles. For MODIS there is no systematic difference with Ångström exponent, whereas for MISR the agreement is best for the largest particles (small Ångström exponents). The values discussed above for MISR at Helgoland and Gotland, and Taiwan influence the analysis for the small particles.

\section{Summary and discussion}

In this study monthly mean aerosol optical depth (AOD) is compared from a total of nine aerosol retrievals during a 40 months period, from September 1997 to December 2000. We have identified that differences in various satellite retrievals are substantial and even larger than found in an earlier study based on five different aerosol retrievals during a period of eight months prior to the period analysed here. Aerosol remote sensing from space is a complicated task involving a wide range of physical processes that must be taken into account. Issues related to cloud screening are particularly important. It appears that one problem is that, in many retrievals, the cloud screening is not strict enough resulting in AOD being contaminated by clouds. On the other hand it also appears that some aerosol retrievals are too strict, i.e. high aerosol loadings are classified as clouds and thus no aerosol information is retrieved. In this study we have seen examples of aerosol retrievals adopting upper threshold values for AOD in an effort to avoid cloud influence. For small particles (e.g. from industrial pollution or biomass burning) this procedure could be improved by introducing an additional criterion for the Ångström exponent. However, this is more difficult for larger particles (e.g. mineral dust and sea salt) with smaller Ångström exponents more similar to those of clouds. For example, retrieval of aerosol information under major dust episodes, where AOD can be significantly above 1.0 is particularly difficult. To distinguish heavy dust loads from clouds is difficult and multi channel information is needed. Dedicated aerosol satellite instruments have this capacity and therefore this is a tractable problem for these retrievals. Additionally, in conditions of heavy dust loading, sunphotometers may screen out heavy dust loadings by missclassification as cloud. During the SHADE campaign there was an indication that during the period of maximum AOD during a major dust storm, the procedure for processing level 1.5 to level 2 sunphotometer data led to rejection of much of the sun-photometer data (Haywood et al., 2003). Overall, it cannot be ruled out that both sunphotometers and satellite retrievals miss-classify some of the major dust storms as clouds and thus are biased towards lower dust conditions.

Despite the fact that the differences in AOD are substantial, there are also many promising results. The agreement with regard to spatial and temporal distribution in AOD between the two dedicated aerosol instruments in many of the subregions investigated in this study is impressing. This finding is both based on the averaged AOD and its variation in magnitude, as well as spatial and temporal correlation coefficient. Furthermore, in several regions the other aerosol retrievals compare well to MODIS and MISR. It seems that for comparisons in smaller regions the agreement between the aerosol retrievals is best where the influence of only few aerosol types is typical.

The analysis performed in this study has been used to identify regions with patterns of agreement and disagreement. The seasonal variation in AOD is well reproduced by the aerosol retrievals at Angola Basin, east coast of USA, Arabian Sea, and Red Sea. The magnitude of the seasonal variation differs between the retrievals, but their timing of maximum in AOD in June or July is very similar. For these four regions the main aerosol components vary substantially such as biomass burning aerosols, aerosols from fossil fuel use, and mineral dust. The spatial correlation in AOD for the aerosol retrievals shows also good results for three of these regions, namely Angola Basin, Arabian Sea, and Red Sea. In addition the spatial correlation at the Cape Verde Plateau is high between many of the retrievals. Several of the AERONET stations show good agreement. The pattern found at the stations Bahrain, Barbados, Bermuda, Venice, and Wallops are the most encouraging.

This study clearly shows that the disagreement between aerosol satellite retrievals is particularly large during events of large influence of aerosols, with differences in AOD over a factor of 3. Part of this difference arises from upper thresholds in AOD, but this can certainly not explain all the difference. During the INDOEX campaign the difference in AOD between four of the retrievals was relatively small, and smaller than during the other major aerosol campaigns. It is noticeable that MODIS and MISR mostly have higher AOD during the events studies here than the other retrievals. We have identified the Caspian Sea as the region having the largest disagreement between the aerosol retrievals. This is in regard to the magnitude of AOD, its temporal variation, and spatial correlation. The spatial correlation between the aerosol satellite retrievals is very weak for the Caspian Sea 

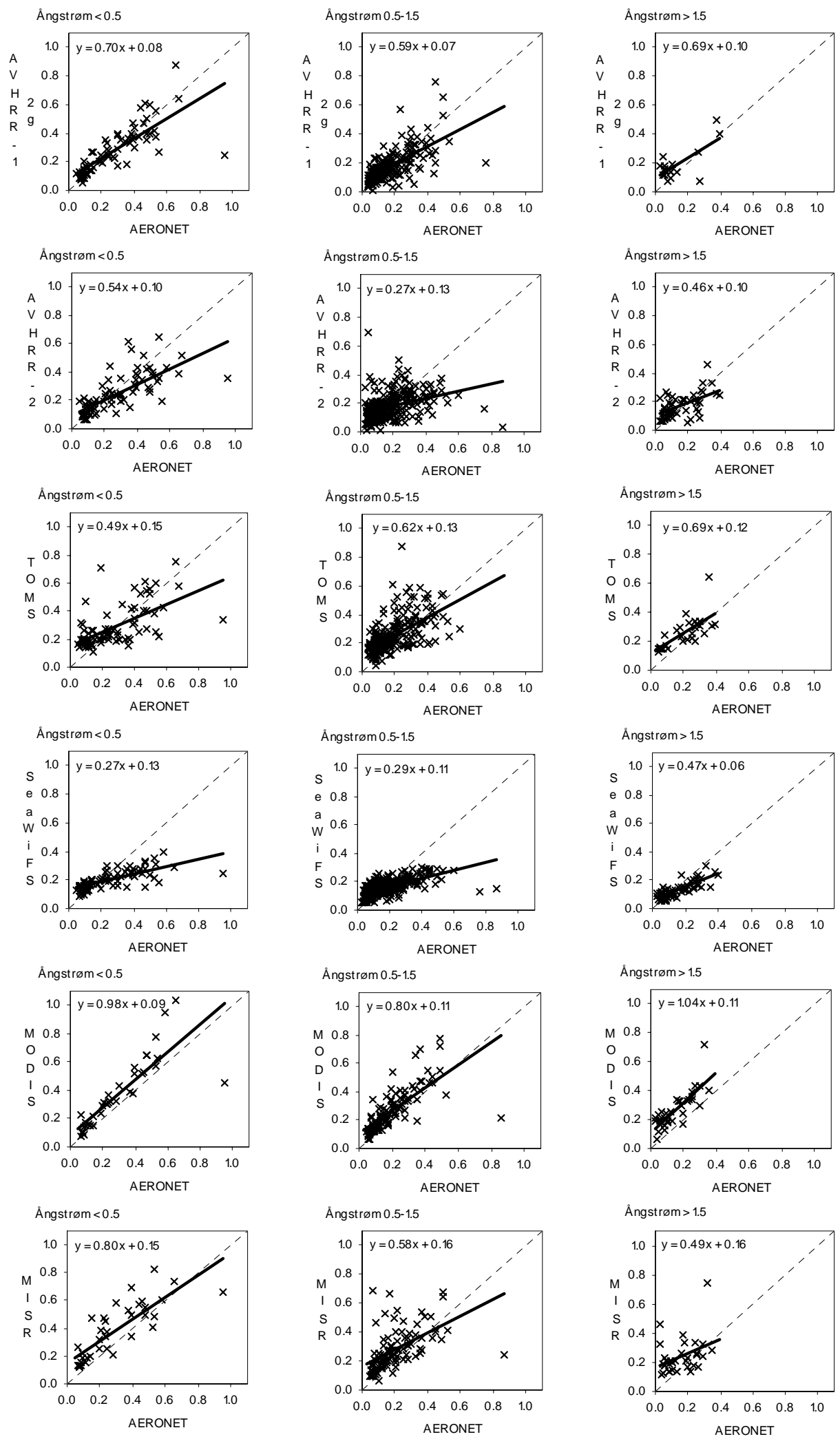

Fig. 11. Scatter plot of monthly mean AOD for AERONET data vs. satellite retrievals. The analysis is divided into three groups depending on the AERONET Ångström exponent. 

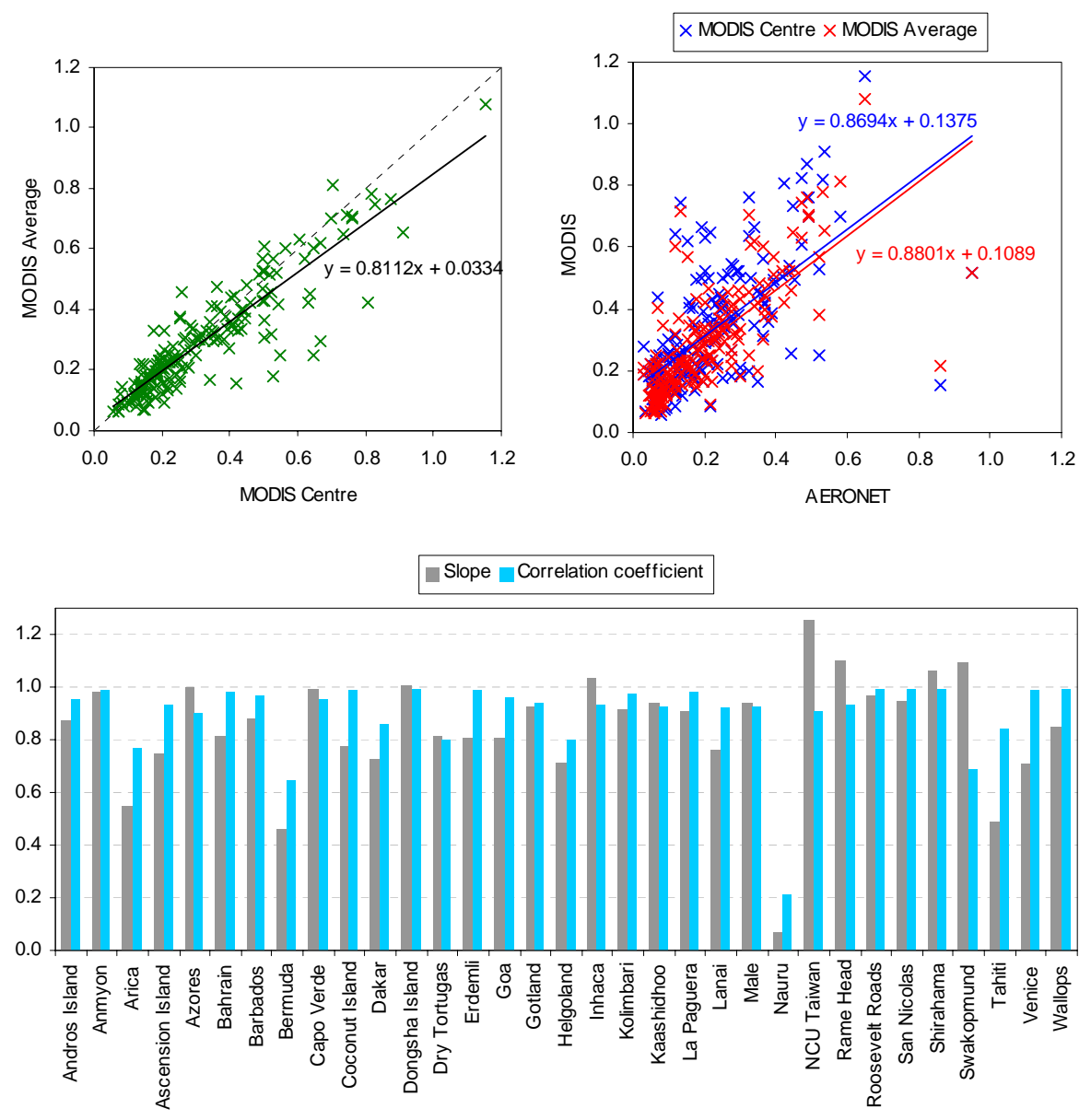

Fig. A1. (A1a) Scatter plot of AOD in grid squares where AERONET stations are located (MODIS Centre) and average AOD for nine grid squares where the AERONET stations are located in the centre square (MODIS Average). (A1b) Scatter plot of AOD from AERONET and AOD from MODIS grid squares where the AERONET stations are located (MODIS Centre) and AOD average for nine grid squares where the AERONET stations are located in the centre grid square (MODIS Average). (A1c) Slope and correlation resulting from a regression analysis between AOD from MODIS grid squares where the AERONET stations are located (MODIS Centre) and AOD average for nine grid squares where the AERONET stations are located in the centre grid square (MODIS Average). Results are given for each of the AERONET stations.

and for MODIS and MISR it is even weakly anti-correlated. The Black Sea and Mediterranean Sea are also regions with poor agreement. Particularly large differences between the satellite retrievals are found over remote oceanic regions, in particular at high latitudes southern hemisphere at the edge of possible retrieval of aerosols. The agreement with AERONET data seems particularly poor at Gotland, Helgoland, Rame Head, and Taiwan.

Comparisons with AERONET data reveal differences among the satellite aerosol retrievals, with MODIS data giving generally the best agreement. Also MISR and AVHRR-1 compare very well against the AERONET data. Note here that the comparison between AERONET and satellite retrievals is based on monthly mean data, so that many factors may influence the comparison such as sampling and cloud screening. A more detailed comparison with AERONET data should be based on daily data, to explore differences and evaluate different aerosol retrievals.
The two retrievals especially suited for aerosol monitoring (MODIS and MISR) are in general in better agreement with AERONET. This is not surprising given fewer limitations (Table 1) compared to the other aerosol retrievals investigated. MISR data have been shown to be in even better agreement with AERONET over inland areas on a daily basis (Abdou et al., 2005) compared to the agreement between the two found here for oceanic and coastal areas. Limitations like fixed aerosol microphysical models (AVHRR-1 and VIRS), large pixel sizes (TOMS and GOME/ATSR2), and cutoff thresholds for AOD (SeaWiFS and AVHRR-2) are factors that in certain regions impact the quality of the retrievals. However, AVHRR-1 compares well with MODIS and MISR in many coastal regions and with AERONET data. Further, AVHRR-1 and TOMS are generally in best agreement with MODIS and MISR during episodes of large AOD, and in addition AVHRR-2 has a pattern and magnitude of AOD south of $30 \mathrm{~S}$ that is quite similar to MODIS and MISR. For better 

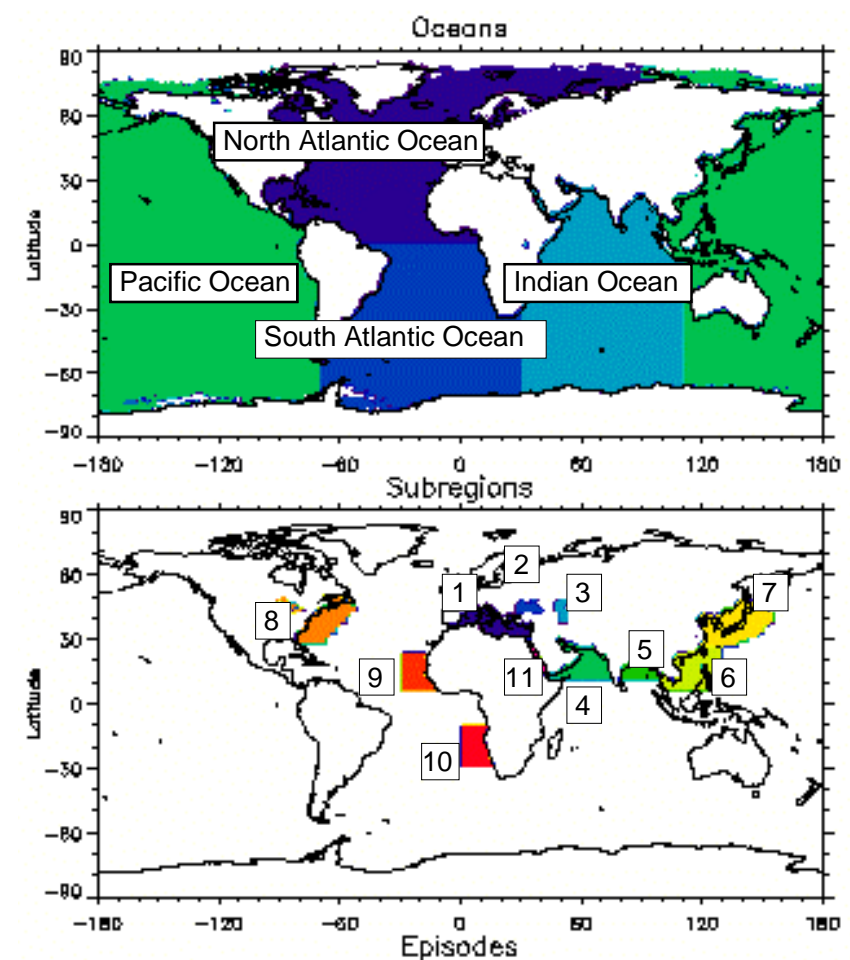

\begin{tabular}{|ll|}
\hline 1 & Mediterranean Sea \\
2 & Black Sea \\
3 & Caspian Sea \\
4 & Arabian Sea \\
5 & Bay of Bengal \\
6 & South China Sea \\
7 & East China Sea and Sea of \\
& Japan \\
8 & East Coast of USA \\
9 & Cape Verde Plateau \\
10 & Angola Basin \\
11 & Red Sea \\
\hline
\end{tabular}

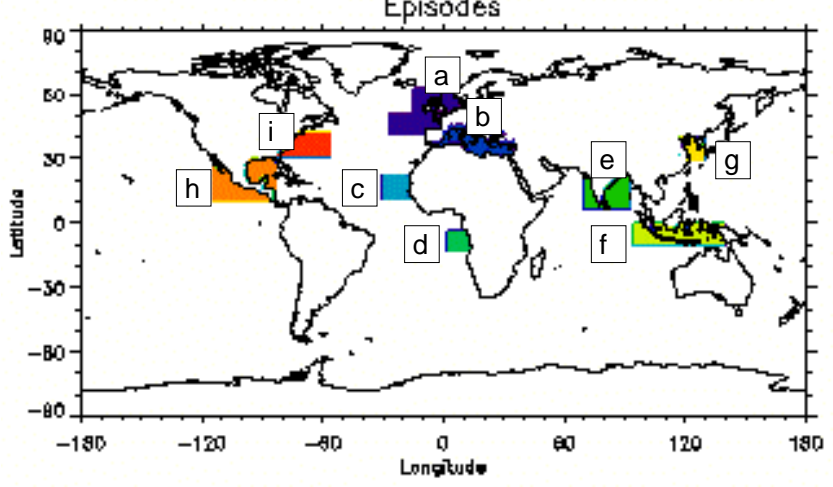

\begin{tabular}{|ll|}
\hline a & Europe Atlantic Coast \\
b & Mediterranean Sea \\
c & Cape Verde Plateau \\
d & Angola Coast \\
e & Indian Coast \\
f & Indonesia \\
g & China Sea \\
h & Mexico \\
i & East Coast USA \\
\hline
\end{tabular}

Fig. A2. Regions used in various analyses in this study (see text in Appendix 2).

aerosol characterization (like small/coarse ratio), data from especially suited instruments like MODIS and MISR or combined products like GOME/ATSR-2 are required.

A wide range of factors determine the accuracy of the retrievals and thus how well different retrievals compare. Note here that an agreement in monthly mean AOD in certain regions could be a coincidence and due to compensating errors. Among factors important for the quality of the remote sensing of aerosols are both connected to instrumental designs and to retrieval limitations or weaknesses. Instrumental dependences related to calibration issues, numbers of spectral channels available for aerosol retrieval with weak overlap with non homogenously distributed gases in the atmosphere and potential for cloud screening, and spatial resolution are crucial elements. Also, there are several factors influencing the quality of the retrieval algorithm such as choice of ra- diative transfer code, treatment of surface reflectance, cloud screening procedure, and aerosol microphysical model. The potential of the aerosol microphysical model used in the retrieval depends to a large degree on the instrumental designs, but also several user specifications are important. This is for instance related to the single scattering albedo of the aerosols. In our intercomparison study also different equatorial passing times could be of importance, despite Kaufman et al. (2000) showed that diurnal variation in AOD was small. However, the equatorial passing time influences the sampling of the data, such as the cloud screening, sun glint screening, and quality control.

To explain the causes of the various analyses in this study a very thorough and tedious investigations must be made. First of all detailed analysis based on daily data must be performed, including comparison with ground based 
sunphotometers, lidars as well as ideally with aircraft measurements. An investigation of how a comparison on daily data relates to a monthly comparison is also needed. To fully understand the causes of differences between datasets a detailed investigation including testing of various parts of the algorithms needs to be made. Future studies should also investigate AOD over land and the Ångström exponent.

\section{Appendix A}

To assess whether the eight nearby grid points can be representative in addition to the grid point with an AERONET station we use MODIS which retrieves data over land and ocean. Note here that we here in many cases apply the ocean retrieval described in this study as well as a land retrieval (Kaufman et al., 1997). In Fig. Ala a scatter plot between MODIS average ( 9 grid points) and MODIS centre (1 grid point) is shown for 10 months for all the 33 AERONET stations. Overall the agreement is reasonably good with some few cases where the MODIS centre has somewhat higher AOD than the MODIS average. Figure Alb shows a scatter plot of MODIS data with AERONET data for both MODIS average and MODIS centre. Results for the two datasets show rather similar agreement with AERONET data. To investigate whether the differences found for MODIS average and MODIS centre in Figure A1a and A1b are particularly large for certain stations, results for each station are given in Fig. A1c. Figure A1c shows that the agreement between MODIS average and MODIS centre is very good except for 3 locations, namely Arica, Bermuda, and Nauru. Therefore, using 9 grid points in the comparison with the AERONET data seems reasonable, but some precaution when comparing with Arica, Bermuda, and Nauru should be taken. In a detailed analysis of the performance of the satellite retrievals higher resolution data than $1 \times 1$ degrees should be used. Local pollution may also cause differences between AERONET and satellite retrievals.

\section{Appendix B}

In this study we have analyzed data adopting in many cases datasets selected for certain regions and certain time periods. Figure A2 shows the area definition of the oceanic regions chosen in this study. In Fig. A2a the 5 major oceanic regions are given (used in the presentation in Fig. 4), whereas in Fig. A2b the 11 subregions are shown (used in Figs. 5 and 6). The regions for the episodes (as given in Fig. 7) with high AODs are illustrated in Fig. A2c.

Edited by: Y. Balkanski

\section{References}

Abdou, W. A., Diner, D. J., Martonchik, J. V., Bruegge, C. J., Kahn, R. A., Gaitley, B. J., Crean, K. A., Remer, L. A., and Holben, B.: Comparison of coincident Multiangle Imaging Spectroradiometer and Moderate Resolution Imaging Spectroradiometer aerosol optical depths over land and ocean scenes containing Aerosol Robotic Network sites, J. Geophys. Res., 110, D10S07, doi:10.1029/2004JD004693, 2005.

Anderson, T. L., Charlson, R. J., Winker, D. M., Ogren, J. A., and Holmen, K.: Mesoscale variations of tropospheric aerosols, J. Atmos. Sci., 60, 119-136, 2003.

Boucher, O. and Tanre, D.: Estimation of the aerosol perturbation to the Earth's radiative budget over oceans using POLDER satellite aerosol retrievals, Geophys. Res. Lett., 27, 1103-1106, 2000.

Geogdzhayev, I. V., Mishchenko, M. I., Rossow, W. B., Cairns, B., and Lacis, A. A.: Global two-channel AVHRR retrievals of aerosol properties of the ocean for the period of NOAA-9 observations and preliminary retrievals using NOAA-7 and NOAA-11 data, J. Atmos. Sci., 59, 262-278, 2002.

Geogdzhayev, I. V., Mishchenko, M. I., Liu, L., and Remer, L.: Global two-channel AVHRR Aerosol climatology: effects of stratospheric aerosols and preliminary comparisons with MODIS and MISR retrievals, J. Quant. Spectrosc. Radiat. Transfer, 88, 47-59, 2004.

Gordon, H. R. and Wang, M.: Retrieval of water-leaving radiance and aerosol optical thickness over the oceans with SeaWiFS: A preliminary algorithm, Appl. Opt., 33, 443-452, 1994.

Haywood, J. M., Ramaswamy, V., and Donner, L. J.: A limitedarea-model case study of the effects of sub-grid scale variations in relative humidity and cloud upon the direct radiative forcing of sulfate aerosol, Geophys. Res. Lett., 24, 143-146, 1997.

Haywood, J. and Boucher, O.: Estimates of the direct and indirect radiative forcing due to tropospheric aerosols: A review, Rev. Geophys., 38, 513-543, 2000.

Haywood, J. M., Francis, P., Osborne, S., Glew, M., Loeb, N., Highwood, E., Tanré, D., Myhre, G., Formenti, P., and Hirst, R.: Radiative properties and direct radiative effect of Saharan dust measured by the C-130 aircraft during SHADE: 1. Solar spectrum, J. Geophys. Res., 108, 8577, doi:10.1029/2002JD002687, 2003.

Hess, M., Köpke, P., and Schult, I.: Optical Properties of Aerosols and Clouds: The Software package OPAC, Bull. Am. Met. Soc., 79, 831-844, 1998.

Holben, B. N., Eck, T. F., Slutsker, I., Tanre, D., Buis, J. P., Setzer, A., Vermote, E., Reagan, J. A., Kaufman, Y. J., Nakajima, T., Lavenu, F., Jankowiak, I., and Smirnov, A.: AERONET: A federated instrument network and data archive for aerosol characterization, Remote Sens. Environ., 66, 1-16, 1998.

Holzer-Popp, T., Schroedter, M., and Gesell, G.: Retrieving aerosol optical depth and type in the boundary layer over land and ocean from simultaneous GOME spectrometer and ATSR-2 radiometer measurements, 1, Method description J. Geophys. Res., 107, 4578, doi:10.1029/2001JD002013, 2002a.

Holzer-Popp, T., Schroedter, M., and Gesell, G.: Retrieving aerosol optical depth and type in the boundary layer over land and ocean from simultaneous GOME spectrometer and ATSR-2 radiometer measurements, 2, Case study application and validation, J. Geophys. Res., 107, 4770, doi:10.1029/2002JD002777, 2002b.

Husar, R. B., Prospero, J. M., and Stowe, L. L.: Characterization of tropospheric aerosols over the oceans with the NOAA ad- 
vanced very high resolution radiometer optical thickness operational product, J. Geophys. Res., 102, 16 889-16909, 1997.

Ignatov, A. and Nalli, N.: Aerosol retrievals from multiyear multisatellite AVHRR Pathfinder Atmosphere (PATMOS) data set for correcting remotely sensed sea surface temperature, J. Tech., 19, 1986-2008, 2002.

Ignatov, A. and Stowe, L.: Physical basis, premises, and selfconsistency checks of aerosol retrievals from TRMM VIRS, J. Appl. Meteorol, 39, 2259-2277, 2000.

Ignatov, A. and Stowe, L.: Aerosol retrievals from individual AVHRR channels: I. Retrieval algorithm and transition from Dave to 6 S radiative transfer model, J. Atmos. Sci., 59, 313-334, 2002a.

Ignatov, A. and Stowe, L.: Aerosol retrievals from individual AVHRR channels: II. Quality control, probability distribution functions, information content and consistency checks of retrievals, J. Atmos. Sci., 59, 335-362, 2002b.

Ignatov, A.: Spurious Signals in TRMM/VIRS Refelectance channels and their effect on aerosol retrievals, J. Tech., 20, 11201137, 2003.

Ignatov, A., Sapper, J., Laszlo, I., Nalli, N., and Kidwell, K.: Operational Aerosol Observations (AEROBS) from AVHRR/3 onboard NOAA-KLM satellites, J. Tech., 21, 3-26, 2004.

Intergovernmental Panel on Climate Change (IPCC), Climate change 2001: The Scientific Basis, edited by: Houghton, J. T., Ding, Y., Griggs, D. J., Noguer, M., van der Linden, P. J., Dai, X., Maskell, K., and Johnson, C. A., Cambridge University Press, 2001.

Kahn, R., Banerjee, P., McDonald, D., and Diner, D. J.: Sensitivity of multiangle imaging to aerosol optical depth and to pureparticle size distribution and composition over ocean, J. Geophys. Res., 103, 32 195-32 213, 1998.

Kahn, R., Banerjee, P., and McDonald, D.: Sensitivity of multiangle imaging to natural mixtures of aerosols over ocean, J. Geophys. Res., 106, 18 219-18 238, 2001.

Kahn, R. A, Gaitley, B. J., Martonchik, J. V., Diner, D. J., Crean, K. A., and Holben, B.: Multiangle Imaging Spectroradiometer (MISR) global aerosol optical depth validation based on two years of coincident Aerosol Robotic Network (AERONET) observations, J. Geophys. Res., 110, D10S04, doi:2004JD00406, 2005.

Kaufman, Y. J. and Fraser R.S.: The effect of smoke particles on clouds and climate forcing, Science, 277, 1636-1639, 1997.

Kaufman Y. J., Tanré, D., Remer, L., Vermote, E., and Holben, B. N.: Operational Remote Sensing of Tropospheric Aerosols over the Land from EOS-MODIS, J. Geophys. Res., 102, $17051-$ 17 068, 1997.

Kaufman, Y. J. Holben, B. N., Tanré, D., Slutsker, I., Smirnov, A., and Eck, T. F.: Will aerosol measurements from Terra and Aqua polar orbiting satellites represent the daily aerosol abundance and properties? Geophys. Res. Lett., 27, 3861-3864, 2000.

Kaufman, Y. J., Tanré, D., and Boucher, O.: A satellite view of aerosols in the climate system, Nature, 419, 215-223, 2002a.

Kaufman, Y. J., Tanré, D., Holben, B. N., Mattoo, S., Remer, L. A., Eck, T. F., Vaughan, J., and Chatenet, B.: Aerosol radiative impact on spectral solar flux at the surface, derived from principalplane sky measurements, J. Atmos. Sci., 59, 635-646, 2002 b.

King, M. D. Kaufman, Y. J., Tanré, D., and Nakajima, T.: Remote sensing of tropospheric aerosols from space: Past, present, and future, Bull. Am. Meteorol. Soc., 80, 2229-2259, 1999.

Koch, D., Park, J., and Del Genio, A.: Clouds and sulfate are anticorrelated: A new diagnostic for global sulfur model, J. Geophys. Res., 108, 4781, doi:10.1029/2003JD003621, 2003.

Koren, I., Kaufamn, Y. J., Remer, L. A. and Martins, J. V.: Measurements of the effect of Amazon smoke on inhibition of cloud formation, Science, 303, 1342-1345, 2004.

Kriebel, K. T., Gesell, G., Kästner, M., and Mannstein, H.: The cloud analysis tool APOLLO: Improvements and Validation, Int. J. Rem. Sens., 24, 2389-2408, 2003.

Kriebel, K. T., Saunders, R. W., and Gesell, G.: Optical Properties of Clouds Derived from Fully Cloudy AVHRR pixels, Beitr. Phys. Atmos., 62, 165-171, 1989.

Liu, L., Mishchenko, M. I., Geogdzhayev, I., Smirnov, A., Sakerin, S. M., Kabanov, D. M., and Ershov, O. A.: Global validation of two-channel AVHRR aerosol optical thickness retrievals over the oceans, J. Quant. Spectrosc. Radiat. Transfer, 88, 97-109, 2004.

Martins, J. V., Tanré, D., Remer, L. A., Kaufman, Y. J., Mattoo, S., and Levy, R.: MODIS Cloud screening for remote sensing of aerosol over oceans using spatial variability, Geophys. Res. Lett., 29, doi:10.1029/2001GL013252, 2002.

Martonchik, J. V., Diner, D. J., Crean, K. A., and Bull, M. A.: Regional aerosol retrieval results from MISR, IEEE Trans. Geosci. Remt. Sensing, 40, 1520-1531, 2002.

Martonchik, J. V., Diner, D. J., Kahn, R. A., Ackerman, T. P., Verstraete, M. E., Pinty, B., and Gordon, H. R.: Techniques for the retrieval of aerosol properties over land and ocean using multiangle imaging, IEEE Trans. Geosci. Remt. Sensing, 36, 12121227, 1998.

Mishchenko, M. I., Geogdzhayev, I. V., Cairns, B., Rossow, W. B., and Lacis, A. A.: Aerosol retrievals over the ocean by use of channels 1 and 2 AVHRR data: sensitivity analysis and preliminary results, Appl. Opt., 38, 7325-7341, 1999.

Mishchenko, M. I., Geogdzhayev, I. V., Liu, L., Ogren, J. A., Lacis, A. A., Rossow, W. B., Hovenier, J. W., Volten, H., and Muoz, O.: Aerosol retrievals from AVHRR radiances: effects of particle nonsphericity and absorption and an updated long-term global climatology of aerosol properties, J. Quant. Spectrosc. Radiat. Transfer, 79/80, 953-972, 2003.

Myhre, G., Jonson, J. E., Bartnicki, J., Stordal, F., and Shine, K. P.: Role of spatial and temporal variations in the computation of radiative forcing due to sulphate aerosols: A regional study, Quart. J. Roy. Met. Soc., 128, 973-989, 2002.

Myhre, G., Stordal, F., Johnsrud, M., Ignatov, A., Mishchenko, M. I., Geogdzhayev, I. V., Tanré, D., Deuzé, J. L., Goloub, P., Nakajima, T., Higurashi, A., Torres, O., and Holben, B. N.: Intercomparison of satellite retrieved aerosol optical depth over ocean, J. Atmos. Sci., 61, 499-513, 2004.

Nakajima, T. and Higurashi, A.: A use of two-channel radiances for an aerosol characterization from space, Geophys. Res. Lett., 25, 3815-3818, 1998.

Nakajima, T., Higurashi, A., Kawamoto, K., and Penner, J. E.: A possible correlation between satellite-derived cloud and aerosol microphysical parameters, Geophys. Res. Lett., 28, 1171-1174, 2001.

Ramanathan, V., Crutzen, P. J., Kiehl, J. T., and Rosenfeld, D.: Aerosols, climate and the hydrological cycle, Science, 294, 2119-2124, 2001. 
Remer, L. A., Tanré, D., Kaufman, Y. J., Ichoku, C., Mattoo, S., Levy, R., Chu, D. A., Holben, B., Dubovik, O., Smirnov, A., Martins, J. V., Li, R.-R., and Ahmad, Z.: Validation of MODIS aerosol retrieval over ocean, Geophys. Res. Lett., 29, doi:10.1029/2001GL013204, 2002.

Remer, L. A., Kaufman, Y. J., Tanré, D., Mattoo, S., Chu, D. A., Martins, J. V., Li, R.-R., Ichoku, C., Levy, R. C., Kleidman, R. G., Eck, T. F., Vermote, E., and Holben, B. N.: The MODIS aerosol algorithm, products and validation, J. Atmos. Sci., 62, 947-973, 2005.

Rosenfeld, D., Lhav, R., Khain, A., and Pinsky, M.: The role of sea spray in cleansing air pollution over ocean via cloud processes, Science, 297, 1667-1670, 2002.

Rosenfeld, D.: Suppression of rain and snow by urban and industrial air pollution, Science, 287, 1793-1796, 2000.

Shettle, E. P. and Fenn, R. W.: Models for the Aerosols of the Lower Atmosphere and the Effects of Humidity Variations on Their Optical Properties, U.S. Air Force Geophysics Laboratory, Hanscom Air Force Base, Mass., 1979.

Stowe, L., Ignatov, A., and Singh, R.: Development, validation, and potential enhancements to the second generation operational aerosol product at NOAA/NESDIS, J. Geophys. Res., 102, 16923-16934, 1997.

Stowe, L., Davis, P., and McClain, P.: Scientific basis and initial evaluation of the CLAVR-1 global clear/cloud classification algorithm for the AVHRR, J. Tech., 16, 656-681, 1999.

Stowe, L. L., Jacobowitz, H., Ohring, G., Knapp, K. R., and Nalli, N. R.: The advanced very high resolution radiometer (AVHRR) Pathfinder atmosphere (PATMOS) climate dataset: Initial analyses and evaluations, J. Clim., 15, 1243-1260, 2002.
Tanré, D., Bréon, F. M., Deuzé, J. L., Herman, M., Goloub, P., Nadal, F., and Marchand, A.: Global observation of anthropogenic aerosols from satellite, Geophys. Res. Lett., 28, 45554558, 2001.

Tanré, D., Kaufman, Y. J., Herman, M., and Mattoo, S.: Remote sensing of aerosol properties over oceans using the MODIS/EOS spectral radiances, J. Geophys. Res., 102, 16 971-16988, 1997.

Torres, O., Bhartia, P. K., Herman, J. R., Ahmad, Z., and Gleason, J.: Derivation of aerosol properties from satellite measurements of backscattered ultraviolet radiation: Theoretical basis, J. Geophys. Res., 103, 17 099-17 110, 1998.

Torres, O., Bhartia, P. K., Herman, J. R., Sinyuk, A., Ginoux, P., and Holben, B.: A long-term record of aerosol optical depth from TOMS observations and comparison to AERONET measurements, J. Atmos. Sci., 59, 398-413, 2002.

Trepte, Q., Chen, Y., Sun-Mack, S., Minnis, P., Yong, D., Baum, B., and Heck, P.: Scene identification for the CERES cloud analysis subsystem, Preprints, 10th Conf. on Atm. Radiation. Madison, WI, Amer. Meteorol. Soc., 169-172, 1999.

Vermote, E., Tanré, D., Deuze, J.-L., Herman, M., Morcrette, J. J.: Second Simulation of the satellite signal in the solar spectrum, '6S': An overview, IEEE TGARS, 35, 675-686, 1997.

Wang, M., Bailey, S., and McClain, C. R.: SeaWiFS Provides Unique Global Aerosol Optical Property Data, in: Eos, Transactions, American Geophysical Union, pp. 197, 2000a.

Wang, M., Bailey, S., Pietras, C., McClain, C. R., and Riley, T.: "SeaWiFS aerosol optical thickness matchup analyses," The SeaWiFS Postlaunch Technical Report Series, Vol. 10, p. 39-44, NASA Tech. Memo. 2000-206892, edited by: Hooker, S. B. and Firestone, E. R., NASA Goddard Space Flight Center, Greenbelt, Maryland, 2000b. 